University of Chicago Law School

Chicago Unbound

Public Law and Legal Theory Working Papers

Working Papers

2009

\title{
Gun Control after Heller: Threats and Sideshows from a Social Welfare Perspective
}

Adam M. Samaha

Philip K. Cook

Jens Ludwig

Follow this and additional works at: https://chicagounbound.uchicago.edu/public_law_and_legal_theory

Part of the Law Commons

Chicago Unbound includes both works in progress and final versions of articles. Please be aware that a more recent version of this article may be available on Chicago Unbound, SSRN or elsewhere.

\section{Recommended Citation}

Adam Samaha, Philip K. Cook \& Jens Ludwig, "Gun Control after Heller: Threats and Sideshows from a Social Welfare Perspective" (University of Chicago Public Law \& Legal Theory Working Paper No. 259, 2009).

This Working Paper is brought to you for free and open access by the Working Papers at Chicago Unbound. It has been accepted for inclusion in Public Law and Legal Theory Working Papers by an authorized administrator of Chicago Unbound. For more information, please contact unbound@law.uchicago.edu. 


\section{CHICAGO}

JOHN M. OLIN LAW \& ECONOMICS WORKING PAPER NO. 454

(2D SERIES)

PUblic LAW AND Legal THEORY WORKING PAPER NO. 259

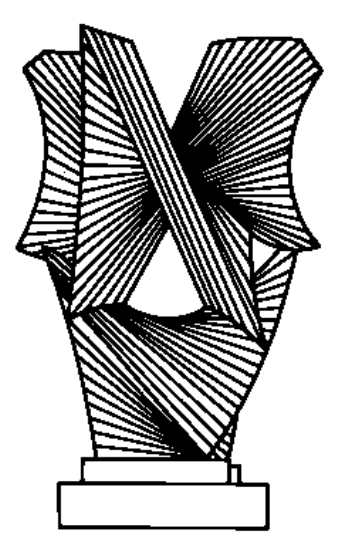

GUN CONTROL AFTER HELLER: THREATS AND SIDESHOWS FROM A SOCIAL WELFARE PERSPECTIVE

Philip J. Cook, Jens Ludwig, and Adam M. Samaha

\section{THE LAW SCHOOL THE UNIVERSITY OF CHICAGO}

February 2009

This paper can be downloaded without charge at the John M. Olin Program in Law and Economics Working Paper Series: http://www.law.uchicago.edu/Lawecon/index.html and at the Public Law and Legal Theory Working Paper Series: http://www.law.uchicago.edu/academics/publiclaw/index.html and The Social Science Research Network Electronic Paper Collection. 


\title{
Gun CONTROL AFTER HELLER: THREATS AND SiDESHOWS FROM A SOCIAL WELFARE PERSPECTIVE
}

\author{
Philip J. Cook ${ }^{*}$ \\ Jens Ludwig \\ Adam M. Samaha
}

What will happen after Heller? We know that the Supreme Court will no longer tolerate comprehensive federal prohibitions on home handgun possession by some class of trustworthy homeowners for the purpose of, and perhaps only at the time of, self-defense. But the judiciary could push further, if nothing else by incorporating Heller's holding into the Fourteenth Amendment and enforcing it against states and municipalities. In fact, the majority opinion offered little guidance for future cases. It presented neither a purely originalist method of constitutional interpretation nor a constraining doctrinal framework for evaluating other regulation-even while it gratuitously suggested that much existing gun control is acceptable. In the absence of more information from the Court, we identify plausible legal arguments for the next few rounds of litigation and assess the stakes for social welfare.

We conclude that some of the most salient legal arguments after Heller have little or no likely consequence for social welfare based on available data. For example, the looming fight over local handgun bans-an issue on which we present original empirical data-seems largely inconsequential. The same can be said for a right to carry a firearm in public with a permit. On the other hand, less prominent legal arguments could be quite threatening. Taxation and regulation targeted especially at firearms might be presumptively disfavored by judges in the future, along the lines of free speech doctrine. This could have serious consequences. In addition, Second Amendment doctrine might generally dampen enthusiasm for innovative regulatory responses to the problem of gun violence. The threat of litigation may inhibit policy experimentation ranging from micro-stamping on shell casings, to pre-market review of gun design, to so-called personalized firearms, and beyond.

* ITT/Terry Sanford Professor of Public Policy Studies; Professor of Economics and Sociology and Associate Director, Terry Sanford Institute of Public Policy.

** McCormick Foundation Professor of Social Service Administration, Law, and Public Policy, The University of Chicago.

*** Assistant Professor of Law and Herbert \& Marjorie Fried Teaching Scholar, The University of Chicago Law School.

We thank participants at the UCLA Law Review symposium on Second Amendment rights, for which this article was written, and Hanna Chung and Aditi Paranjpye for their excellent research assistance. 


\section{CONTENTS}

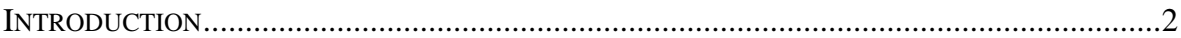

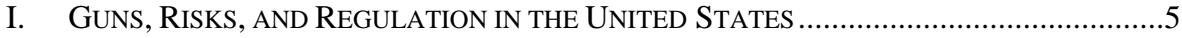

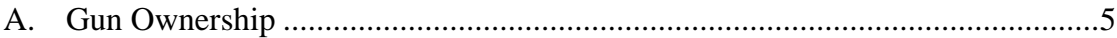

B. Gun Violence ........................................................................................

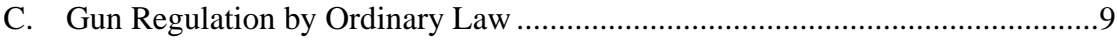

1. Interstate Transactions and Access Restrictions ......................................9

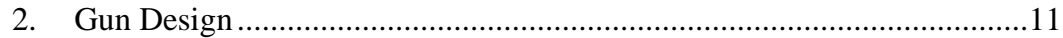

3. Gun Possession and Use ...............................................................13

4. Record Keeping ...............................................................................13

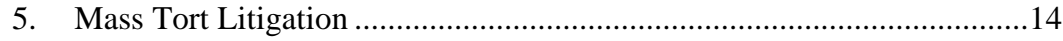

II. HELLER AND THE NEXT LITIGATION FRONTIER .....................................................16

A. Heller's Demilitarized Message ....................................................................

B. Heller's Core Right and Suggested Limits..................................................20

C. Models for Judicial Review After Heller ..........................................................23

III. ON THREATS AND SIDESHOWS TO SOCIAL WELFARE ..............................................27

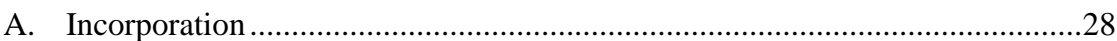

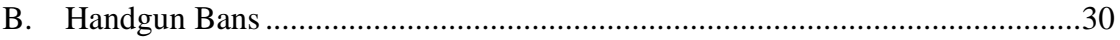

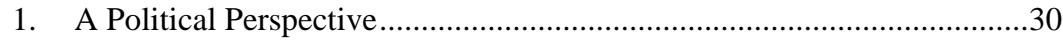

2. A Policy Consequence Perspective .........................................................32

a. Gun Prevalence, Crime, and Public Health ......................................32

b. Will Handgun Prevalence Increase in the District? ............................35

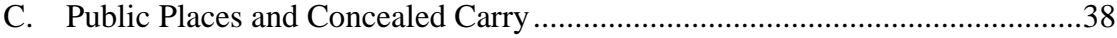

D. Gun-Targeted Taxes, Safety Programs, and Policing....................................41

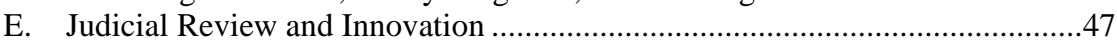

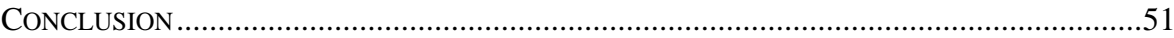

\section{INTRODUCTION}

Judicial opinions on supreme law, no matter how backward-looking their reasoning may appear, are occasions to look forward. They indicate the position of today's judges on issues faced by other institutions, and they signify commitments that these judges are most unwilling to revise. On the other hand, no opinion can fully chart the future path of judicial doctrine any more than regulatory, statutory, or constitutional text can provide undisputed guidance to all readers. Each of these texts must be used by decisionmakers in the future. In fact, the identity of the relevant decisionmakers is bound to change over time, with no guarantee that the new group will mimic the judgment of the old.

Our goal is to consider the plausible future of gun regulation after District of Columbia v. Heller, ${ }^{1}$ without forgetting the limits on accurate

1. $\quad 128$ S.Ct. 2783 (2008). 
predictions. Heller itself decided little about the Second Amendment's scope and the appropriate method by which judges should test for its violation. The majority opinion establishes that a certain class of trustworthy citizens has a judicially enforceable right to an operable handgun in the home for the purpose of self-defense-perhaps only at the time of self-defense-as against a flat federal ban on handgun possession. ${ }^{2}$ The holding leaves many questions undecided. Nor was this case the best test of judicial courage. Opinion polls showed large national majorities opposing such bans. ${ }^{3}$ Equally telling, a majority of United States Senators and House members signed an amicus brief arguing that the District's regulations were unconstitutional. ${ }^{4}$ Thus the political environment intimated little resistance to the narrow outcome in Heller. ${ }^{5}$ After 50,000 words of argument, counterargument, and apparent compromise, the justices delivered little more than a new beginning for Second Amendment arguments in court. ${ }^{6}$

Understanding the hazards of prediction in these circumstances, we take a social welfare perspective on gun control as our point of departure. Our interest is in policy that best serves the overall welfare of the public, including both gun owners and those at risk from gun-related crimes and accidents. We care about judicial decisions that advance or retard such policymaking, but we are less concerned with evaluating the Supreme Court's work according to conventional standards of legal argument or an ideal theory of constitutional interpretation. We would investigate the social welfare consequences of judicially enforceable gun rights even if these rights were plainly dictated by justified fidelity to the true meaning of the Constitution, and even if such rights ought to be understood as trumps to any further cost-benefit analysis. ${ }^{7}$

Although this social welfare perspective is wide-ranging in some respects, it leads us to significant and perhaps surprising conclusions about

2. See infra Part II.A (discussing readings of Heller's holding).

3. See Lydia Saad, Shrunken Majority Now Favors Stricter Gun Laws, GaLluP News SERV., Oct. 11, 2007, available at http://www.gallup.com/poll/101731/Shrunken-Majority-NowFavors-Stricter-Gun-Laws.aspx.

4. See Brief for Amici Curiae 55 Members of United States Senate, the President of the United States Senate, and 250 Members of United States House of Representatives in Support of Respondent, in District of Columbia v. Heller, 128 S.Ct. 2783 (2008). One might ask why these legislators did not prefer to legislate. See infra note 243.

5. Neither major party candidate for president took issue with the outcome after the fact, see http://2008central.net/2008/06/26/mccain-and-obama-statements-on-dc-v-heller, although it is worth noting that John McCain signed the aforementioned amicus brief while Barack Obama did not, see Brief for Amici Curiae, supra note 4, at 39.

6. $\quad$ See infra notes 133-136 (collecting examples of litigation in Heller's wake).

7. See, e.g., Ronald Dworkin, Rights as Trumps, in THEORIES OF RIGHTS 153, 153, 158, 165-66 (Jeremy Waldron ed., 1984). 
the future of sound gun control policy. To be sure, some of the constitutional questions emerging after Heller will be relevant to good public policy. The majority's list of "presumptively" valid regulations will have to be confirmed, ${ }^{8}$ and its view of Second Amendment rights might be extended to state and local governments. These legal questions are obvious and worth debating. But certain Second Amendment issues that are likely to be litigated in the near future might be largely irrelevant to social welfare. An example is the looming fight over state and local handgun bans-an issue on which we present some original empirical data-and the possibility of a qualified Second Amendment right to carry a firearm in public with a permit. On the other hand, certain legal questions that have received less public attention might have much higher stakes from a social welfare perspective. An example is the validity of firearms taxes or safety programs developed especially for firearms. Finally, Heller might be used to dampen enthusiasm for innovative responses to the ongoing clash of gun rights advocates and gun control proponents. We will briefly discuss this concern, along with a faint hope for a better result. ${ }^{9}$

Our analysis proceeds in three steps. Part I offers some data on gun ownership in the United States and a sketch of the country's gun control regime before Heller. Part II explains what was decided and left open by the majority's opinion, and discusses various models that the Supreme Court has used tomodulate supreme judicial review in other fields. Part III considers potential consequences of continued judicial oversight of firearms regulation. Much of the analysis is provisional. But we can suggest danger zones where aggressive judicial intervention would most likely result in troubling consequences for social welfare, as well as disputes that seem unimportant based on current knowledge. The analysis closes with a brief discussion of the potentially complex relationship between judicial review and innovation in gun control.

8. Heller, 128 S.Ct. at 2817 \& n. 26; infra text accompanying note 125.

9. This Article relies on many empirical studies. They will be unfamiliar to most lawyers, and some readers might wish to minimize the studies' value for constitutional decisionmaking. Indeed, the facial plausibility of the data might be influenced by the reader's feelings about gun control. See, e.g., Dan M. Kahan \& Donald Braman, The Self-Defensive Cognition of SelfDefense, 45 AM. CRIM. L. REV. 1, 18-19 (2008). But for our purposes, these empirical studies are essential. We have made best efforts to accurately recount the findings thereinand to draw only logically supportable conclusions therefrom. The data will not, however, perfectly measure the psychological or emotional impact of gun rights and gun ownership. The happiness, satisfaction, fear, and distress arising from the prevalence of guns in America is difficult to measure precisely.

Note also that judicial understandings of constitutional rights can influence the rendering of ordinary law. Statutory interpretation may be influenced by constitutional doubt, and Heller might instigate new constitutional doubt when courts interpret statutes. We set aside the difficult project of predicting and estimating these effects after Heller. 


\section{GUNS, Risks, AND REgUlAtion IN THE UNITED STATES ${ }^{10}$}

\section{A. Gun Ownership}

In America, gun ownership is concentrated. Our best estimate is that there are 200-250 million firearms in private circulation, ${ }^{11}$ meaning that there are nearly enough guns for every adult to have one. But about seventy-five percent of all adults do not own any guns. ${ }^{12}$ Recent survey data suggests that about forty percent of males, about ten percent of females, and about thirty-five percent of all households have at least one gun. ${ }^{13}$ It seems that the prevalence of gun ownership by household has been in long-term decline, ${ }^{14}$ partly because households are becoming smaller and less likely to include an adult male. On the other hand, most people who own one gun own many. In 1994, about seventy-five percent of all guns were owned by those who owned four or more, and this slice of gun owners amounted to only ten percent of the adult population. ${ }^{15}$

Firearms ownership is not only concentrated but also associated with particular geographic locations and socioeconomic traits. The prevalence of

10. This Part draws on material from Philip J. Cook \& Jens Ludwig, The Social Costs of Gun Ownership. 90 J. PUB. ECON. 379 (2006).

11. This estimate is based on two sources: federal tax records on sales and a survey. First, the number of new guns added each year is taken from tax data kept by the federal government on manufactures, imports, and exports. The annual count of net additions can be cumulated over, say, the last century, with some assumption about the rate of removal through such mechanisms as offthe-books exports, breakage, and police confiscation. See GARY KLECK, TARGETING Guns: FIREARMS AND THEIR CONTROL 63-64 (1997); Philip J. Cook, The Technology of Personal Violence, in CRIME AND JUSTICE: A REVIEW OF RESEARCH 1-71 (Michael Tonry ed., 1991). The second basis for estimating the stock is the one-time National Survey of the Personal Ownership of Firearms (NSPOF), conducted in 1994. This is the only survey that has attempted to determine the number of guns in private hands. A number of other surveys, including the General Social Survey, provide an estimate of the prevalence of gun ownership among individuals and households but do not attempt to determine the average number of guns per gun owner. The NSPOF estimate for the number of guns in 1994 was 192 million, a number that is compatible with the "sales accumulation" method, assuming that just fifteen percent of the new guns sold since 1899 have been discarded or destroyed. See Philip J. Cook \& Jens Ludwig, Aiming for Evidence-Based Gun Policy, 25 J. POL. ANAL. \& MAN. 691, 699-700 (2006). Since the NSPOF survey, the annual rate of net additions to the gun stock has been about 4-5 million per year, see BUREAU OF ALCOHOL, TOBACCO \& FIREARMS, FIREARMS COMMERCE IN THE UNITED STATES (2002); BuREAU OF ALCOHOL, TOBACCO \& FIREARMS, FIREARMS COMMERCE IN THE UNITED STATES (2001) — or 50 60 million by 2006. Given a continued removal rate of just one percent, the stock as of 2006 would be about 220 million.

12. See Philip J. COOK \& Jens LudWig, Guns in AMERICA: Results of A COMPREHENSIVE SURVEY OF GUN OWNERSHIP AND USE 24 (1996).

13. See id. at 24,54 .

14. See id. at 9; Tom W. SMith, Public Attitudes Towards the Regulation of FIREARMS 1 \& fig. 2 (2007).

15. See COOK \& LUDWIG, supra note 12, at 13-14, 32. 
gun ownership differs widely across regions, states, and localities, and across different demographic groups. For example, while it appears that about thirteen percent of Massachusetts households own a gun, fully sixty percent of Mississippi households own one. ${ }^{16}$ Residents of rural areas and small towns are far more likely to own a gun than residents of large cities, partly because of the importance of hunting and sport shooting in those communities. And this geographic skew is consistent with a concentration of ownership among middle-aged, middle-income households. ${ }^{17}$ These attributes are associated with relatively low involvement in criminal violence, ${ }^{18}$ and it is reasonable to suppose that most guns are in the hands of people who are unlikely to misuse them. Still, gun owners as a group are more likely than other adults to have a criminal record. ${ }^{19}$

Of the subset of Americans who own firearms, handguns are somewhat popular but by no means the dominant type of weapon. Around thirty-three percent of America's privately held firearms are handguns, which are more likely than long guns to be kept for defense against crime. ${ }^{20}$ In the 1970s, about thirty-three percent of new guns were handguns, a figure which grew to nearly fifty percent by the early 1990s and then fell back to around forty percent. $^{21}$ Despite the long-term increase in the relative importance of handgun sales, a mere twenty percent of gun-owning individuals have only handguns; forty-four percent have both handguns and long guns, reflecting the fact that most people who have acquired guns for self-protection are also hunters and target shooters. ${ }^{22}$ Less than fifty percent of gun owners say that their primary motivation for having a gun is self-protection against crime. ${ }^{23}$

Most Americans get their guns from regulated dealers, but a significant number of acquisitions are either less regulated or criminal. The majority of guns in circulation were obtained by their owners directly from a federally licensed firearm dealer (FFL). ${ }^{24}$ However, the thirty to forty percent of all

16. See D. Azrael, Philip J. Cook \& Matthew Miller, State and Local Prevalence of Firearms Ownership: Measurement, Structure, and Trends, 20 J. QUANTITATIVE CRIMINOLOGY 43 (2004).

17. See CoOK \& LUDWIG, supra note 15, at 53-55.

18. See Ching-Chi Hsieh \& M. D. Pugh, Poverty, Income Inequality, and Violent Crime: A Meta-Analysis of Recent Aggregate Data Studies, 18 CRIM. JusTICE REV. 182, 198 (1993) (showing a correlation between poverty, income inequality, and violent crime); Federal Bureau of Investigation, Crime in the United States 2007 (table 38), available at http://www.fbi.gov/ucr/cius2007/data/table_38.html (indicating that only about 23\% of violent crimes are committed by people between ages 30 and 50).

19. See id. at 35.

20. See id. at 14-16, 37-39.

21. See Bureau of Alcohol, Tobacco \& Firearms, U.S. DePt. OF the Treasury, COMMERCE IN FIREARMS IN THE UNITED STATES 7 (2000) (dating the decline at 1997).

22. See COOK \& LUDWIG, supra note 15, at 53.

23. See id. at 56 .

24. See id. at 31 . 
gun transfers that do not involve licensed dealers-the so-called secondary market $^{25}$-accounts for most guns used in crime. ${ }^{26}$ Despite the prominence of gun shows in contemporary policy debates, the best available evidence suggests that such shows account for only a small share of all secondary market sales. ${ }^{27}$ Another important source of crime guns is theft. Over 500,000 guns are stolen each year. ${ }^{28}$

\section{B. Gun Violence}

Including homicide, suicide, and accidental deaths, 30,694 Americans died by gunfire in 2005. This amounts to a gun-related mortality rate of 10.4 deaths per 100,000 people for the year. ${ }^{29}$ The mortality rate is down substantially from 1990, when it was 14.9 per 100,000 , but is still much higher than the observed rate in, say, $1950 .^{30}$

Intentional violence is the major exception to the general decline in death by injury during the last fifty years. ${ }^{31}$ More Americans die each year by gun suicide than gun homicide. ${ }^{32}$ However, more people suffer nonfatal gun injuries from crime than from unsuccessful suicide attempts. The case fatality rate, which is much higher for attempted suicide than for gunshot wounds from criminal assaults, accounts for this difference. In addition, 800 people per year die from unintentional gunshot injuries, although this figure is heavily influenced by coroners' standards concerning what constitutes an accident as opposed to a homicide or suicide. ${ }^{33}$

Although everyone shares in the costs of gun violence to some extent, the shooters and victims are not a representative slice of the population. In

25. See Philip J. Cook, Stephanie Molliconi, \& Thomas B. Cole, Regulating Gun Markets, 86 J. CRIM. L. \& CRIMINOLOGY 59 (1995).

26. See James D. Wright \& PETER H. Rossi, ARMEd AND CONSIDERED DANGERous: A SURVEY OF FELONS AND THEIR FIREARMS 4 (expanded ed. 1994); JOSEPH F. SHELEY \& JAMES D. WRIGHT, IN THE LINE OF FIRE: YOUTH, GUNS, AND VIOLENCE IN URBAN AMERICA (1995); Philip J. Cook \& Anthony A. Braga, Comprehensive Firearms Tracing: Strategic and Investigative Uses of New Data on Firearms Markets, 43 ARIZ. L. REV. 277, 291-92 (2001).

27. See COOK \& LUDWIG, supra note 15, at 25 tbl. 3.11.

28. See id. at 41; KLECK, supra note 11, at 90.

29. See Centers for Disease Control \& Prevention, National Center for Injury Prevention \& Control, WISQARS Fatal Injuries: Mortality Reports, available at http://webappa.cdc.gov/sasweb/ncipc/mortrate.html (accessed Sept. 8, 2008) [hereinafter WISQARS].

30. See Philip J. COOK \& Jens LudWig, Gun Violence: The REAl Costs 18-19 (2000); U.S. DeP'T of Health, Ed. \& Welfare, Vital Statistics of the United States 77-78 (1950), available at http://www.cdc.gov/nchs/data/vsus/VSUS_1950_3.pdf.

31. See COOK \& LUDWIG, supra note 30, at 21-27.

32. See Center for Disease Control \& Prevention, National Vital Statistics REPORTS-DEATHS: PRELIMINARY DATA FOR 2006, at 20 (2008), available at http://www.cdc.gov/nchs/data/nvsr/nvsr56/nvsr56_16.pdf.

33. See id. at 19, 37. 
2005, the gun homicide victimization rate for Hispanic men ages 18-29 was six times the rate for nonHispanic white men of the same age. ${ }^{34}$ And the gun homicide rate for black men ages 18-29-99 per 100,000 — was a remarkable twenty-four times the rate for white males in that age group. ${ }^{35}$ In addition, there appears to be considerable overlap between the populations of potential offenders and victims: the large majority of both groups have prior criminal records. ${ }^{36}$ The demographics of gun suicide look somewhat different. While suicides and homicides both occur disproportionately among those with low incomes or educational attainment, gun suicides are more common among whites than blacks, and more common among the old than among young or middle-aged adults. ${ }^{37}$ Men are vastly overrepresented in all categories.

However, the costs of gun violence to society are more evenly distributed across the population than victimization statistics might suggest. The threat of being shot prompts private citizens and public institutions to undertake a variety of costly measures to reduce this risk, and many people live with anxiety arising from the lingering chance that they or a loved one could be shot. As one local district attorney notes, "Gun violence is what makes people afraid to go to the corner store at night." 38 As a result, the threat of gun violence in some neighborhoods is an important disamenity that depresses property values and economic development. Gun violence, then, is a multifaceted problem that has notable effects on public health, crime, and living standards.

While quantifying the magnitude of these social costs is difficult, one contingent-valuation (CV) survey estimate found that the costs of gun violence were on the order of $\$ 100$ billion in $1995 .^{39}$ Most of these costs (\$80 billion) come from crime-related gun violence. ${ }^{40}$ Dividing by the

\footnotetext{
34. See WISQARS, supra note 29.

35. See WISQARS, supra note 29.

36. See David M. Kennedy, Anne M. Piehl \& Anthony A. Braga, Youth Violence in Boston: Gun Markets, Serious Youth Offenders, and a Use-Reduction Strategy, 59 L. \& CONTEMP. PROBS. 147, 191 tbls. 1 \& 2 (1996); Michael D. McGonigal et al., Urban Firearm Deaths: A Five-Year Perspective, 35 J. Trauma 532 (1993); Philip J. Cook, Jens Ludwig \& Anothony A. Braga, Criminal Records of Homicide Offenders, 294 J. AMER. MED. ASSN. 598 (2005); see also Don B. Kates, Jr. \& Daniel D. Polsby, The Myth of the "Virgin Killer": Law-Abiding Persons Who Kill in Fit of Rage 19-20 (2000) (unpublished manuscript), available at http://www.hoffmang.com/firearms/kates/Myth_of_the_Virgin_Killer-Kates-Polsby.pdf.

37. See CoOK \& LUDWIG, supra note 30, at 23-24.

38. J. Kalil, A New Approach: Prosecutors Take Aim at Gun Crimes, LAS VEGAS REV.-J., Mar. 9, 2002, at 1B.

39. See COOK \& LUDWIG, supra note 30 , at 11.

40. See id. at 10
} 
annual number of crime-related gunshot wounds, including homicides, implies a social cost per crime-related gun injury of around $\$ 1$ million. ${ }^{41}$

\section{Gun Regulation by Ordinary Law}

While far less stringent than regulation in other wealthy nations, ${ }^{42}$ state and federal law in the United States regulates most aspects of firearms commerce and possession. It should be noted up front, however, that gun regulation in the United States is almost entirely a product of legislation rather than rulemaking processes in administrative agencies. The latter would tend to place greater demands on the decisionmakers to solicit alternative viewpoints and to show a serious consideration of costs and benefits. The legislative process tends to have no such formal requirements before enactment.

\section{Interstate Transactions and Access Restrictions}

A primary objective of federal gun regulation is to minimize policy spillover across state lines. The balance between benefit and cost in gun possession and regulation differs widely across states. Federal law aims to ensure that stringent regulations on firearms commerce in some states are not undercut by relatively lax regulation in other states. ${ }^{43}$ The citizens of rural Montana understandably favor a more permissive system than those living in Chicago, and both can be accommodated if transfers between them are effectively limited. In response to such concerns, the Gun Control Act of $1968^{44}$ established the framework for the current system of controls on

41. See Jens Ludwig \& Philip J. Cook, The Benefits of Reducing Gun Violence: Evidence From Contingent-Valuation Survey Data, 22 J. RISK \& UNCERTAINTY 207, 213-14 (2001). This estimate is intended to capture the costs of gun misuse and so ignores the benefits to society from widespread gun ownership-in the same way that studies of the social costs of automobile accidents ignore the benefits from driving. The figure comes, in part, from CV responses about what people say they would pay to reduce crime-related gun violence by 30 percent. One potential concern is that these estimates assume that societal willingness to pay to reduce gun violence is linear with the proportion of gun violence eliminated, which may not be the case. And in practice there remains some uncertainty about the reliability of the CV measurement technology. In any case, most of the estimated costs of gun violence to the United States appear to come from crime, insofar as suicide is treated as a private concern, and the estimated costs of gun crime by COOK \& LUDWIG, supra note 30, at 10-11, fits comfortably next to more recent CV estimates for the social costs of crime more generally. See M.A. Cohen et al., Willingness-to-Pay for Crime Control Programs, 42 CRIMINOLOGY 89 (2004).

42. See David Hemenway, Private Guns, Public Health 2-3 (2004).

43. See Franklin E. Zimring, Firearms and Federal Law: The Gun Control Act of 1968, 4 J. LEGAL STUD. 133 (1975).

44. Pub. L. 90-351, tit. IV, § 902, 82 Stat. 226 (June 19, 1968) \& Pub. L. 90-618, tit. I, $\S 102$, 82 Stat. 1214 (Oct. 22, 1968), codified at 18 U.S.C. §§ 921-930 (2008). 
gun transfers. All shipments of firearms, including mail-order sales, are limited to federally licensed dealers. These dealers are required to obey applicable state and local ordinances and to observe certain restrictions on sales of guns to out-of-state residents. ${ }^{45}$

In addition to controlling regulatory spillover between states, federal law establishes a national regulatory floor of restrictions on the acquisition and possession of guns. Thus the Gun Control Act specifies several categories of people who are denied the right to receive or possess a gun, including illegal aliens, people convicted of a felony or an act of domestic violence, people under indictment, illicit drug users, and those who have at some time been involuntarily committed to a mental institution. ${ }^{46}$ In addition, federally licensed dealers may not sell handguns to people younger than age 21 , or long guns to those younger than $18 .^{47}$ And dealers are required to ask for identification from all would-be buyers, have them sign a form indicating that they are not within a proscribed category, and initiate a criminal history check. ${ }^{48}$ Finally, dealers are required to keep a record of each completed sale and to cooperate with authorities when they need to access those records for gun-tracing purposes. ${ }^{49}$

Notably omitted from federal regulation are gun sales by people not in the business. Such sellers, whether at a gun show or elsewhere, may transfer a gun without keeping a record of sale or performing a background check. ${ }^{50}$ This private sale loophole is a major gap in federal regulation and helps the used gun market thrive.

State regulation provides another layer of restrictions on transfer, possession, and use of firearms. Eleven states require handgun buyers to obtain a permit or license before taking possession, a process that typically entails a fee and a waiting period. ${ }^{51}$ All but a few such transfer-control systems are permissive, however, in that most people are legally entitled to obtain a gun. In the few permitting and licensingjurisdictions that do not have permissive standards, including Massachusetts and New York City, it

45. See 18 U.S.C. § 922(b)-(e) (2008). The McClure-Volkmer Amendment of 1986 eased the restriction on out-of-state purchases of rifles and shotguns. Id. at §§ 922-923. Such purchases are now legal as long as they comply with the regulations of both the buyer's state of residence and the state in which the sale occurs.

46. $\quad$ See id. § 922(d)(4).

47. See id. § 922(b)(1).

48. See id. § 922(d).

49. See id. § 922(s); Legal COMMUnity Against Violence Report, Regulating GuNS IN AMERICA: AN EVALUATION AND COMPARATIVE ANALYSIS OF FEDERAL, STATE, AND SELECTED LOCAL GUN LAWS 145-48 (2008) [hereinafter LCAV REPORT]; Jon S. Vernick \& Stephen P. Teret, A Public Health Approach to Regulating Firearms as Consumer Products, 148 U. PA. L. REV. 1193, 1196 (2000).

50. $\quad$ See 18 U.S.C § 921(a)(21)(C) (2008).

51. See LCAV REPORT, supra note 49, at 162-63. 
is difficult to obtain a handgun legally. Chicago (since 1982) and Washington, D.C. (since 1976) largely prohibited handgun ownership as a matter of formal law-although the District's handgun ban cannot be enforced in all circumstances after Heller. ${ }^{52}$ State legislatures have enacted a variety of more modest restrictions on firearms commerce as well. For example, Virginia, Maryland, and California limit dealers to selling no more than one handgun a month to any one buyer. ${ }^{53}$

\section{Gun Design}

Federal law also imposes some restrictions on gun design, and certain types of firearms are effectively prohibited. The National Firearms Act of 1934 (NFA) ${ }^{54}$ was intended to eliminate Prohibition-era gangster firearms, including sawed-off shotguns, hand grenades, and automatic weapons capable of continuous rapid fire with a single pull of the trigger. ${ }^{55}$ All such weapons had to be registered with the federal government and transfers were subject to a tax of $\$ 200$, which at the time of enactment was confiscatory. ${ }^{56}$ While some of these weapons have remained in legal circulation, the NFA-now amended to ban the introduction of new weapons of this sort $^{57}$-appears to have been quite effective at reducing the use of automatic weapons in crime. ${ }^{58}$

Furthermore, the Gun Control Act of 1968 included a ban on the import of small, cheap handguns, ${ }^{59}$ sometimes known as "Saturday Night Specials." This ban uses criteria to assign points to a gun model depending on its size and other qualities. ${ }^{60}$ Handguns that fail to achieve a minimum score on the factoring criteria, or that fail to meet size and safety criteria, cannot be imported. However, domestic manufacturers may lawfully assemble guns, often from imported parts, that would fail the factoring

52. See infra Part II.A-II.B. On the District's revised rules, see note 113, below.

53. See CAL. PENAL CODE §§ 1207(a)(9), (c)(6), 12071(b)(7)(F) (2008); MD. CodE ANN., Pub. SAFETY § 5-128(a)-(b) (West 2008); VA. CODE ANN. § 18.2-308.3:2(P) (2008); see also LCAV REPORT, supra note 49, at 140-41.

54. 26 U.S.C $\S \S 5801-5872(2008)$.

55. See id. $\S 5845$

56. See id. $\S 5811$.

57. See id. §5861.

58. See GARY KLECK, POINT BLANK: REgUlatiNG GUNS IN AMERICA 67-70 (2005).

59. An important loophole allowed the import of parts of handguns that could not meet the "sporting purposes" test of the Gun Control Act. This loophole was closed by the McClureVolkmer Amendment of 1986. See Zimring, supra note 43, at 155; Philip J. Cook, Mark H. Moore, \& Anthony A. Braga, Gun Control, in CRIME: PUBliC POLICIES FOR CRIME CONTROL 291 (James Q. Wilson \& Joan Petersilia eds., 2002).

60. See Zimring, supra note 43, at 156; TRUDY A. KARLSON \& STEPHEN W. HARGARTEN, REDUCING FIREARM InJURY AND DEATH: A PUBliC HEALTH SOURCEBOOK ON GUNS 74 (1997) (listing some of the factoring criteria for imported guns). 
criteria. This market niche has been well supplied. One study found that one-third of new domestically manufactured handgun models did not meet the size or quality requirements applied to imports. ${ }^{61}$

In 1994, Congress temporarily banned the importation and manufacture of certain assault weapons (military-style semi-automatic firearms). The Crime Control $\mathrm{Act}^{62}$ banned nineteen such weapons by name, and others were outlawed if they possessed some combination of design features such as a detachable magazine, barrel shroud, or bayonet mount. ${ }^{63}$ The Act also banned manufacture and import of magazines holding more than 10 rounds. $^{64}$ However, then-existing assault weapons and large-capacity magazines were grandfathered. ${ }^{65}$ And in 2004, the ban was allowed to expire. $^{66}$

Aside from these design prohibitions, federal law has been permissive. It leaves unregulated those types of firearms that are not specifically banned. Furthermore, firearms and ammunition are excluded from the purview of the Consumer Product Safety Commission. ${ }^{67}$ Nor is there any federal agency with responsibility for reviewing the design of firearms, or any mechanism in place for identifying unsafe models that could lead to a recall and correction. ${ }^{68}$

But some states have acted independently. In 2000, the Massachusetts Attorney General announced that firearms would henceforth be regulated by a state agency with jurisdiction over other consumer products, and firearms judged unacceptable would be taken off the market. ${ }^{69}$ Massachusetts is unique in asserting broad state authority to regulate gun design and safety per se, though a handful of other state legislatures have restricted the design of new guns in more limited fashion. The first important instance occurred in Maryland, which enacted its own ban on Saturday Night Specials. The legislature was responding to a successful suit against a gun manufacturer.

61. See John S. Milne et al., Effect of Current Regulations on Handgun Safety Features, 41 AnN. EMERG. MED. 1 (2003); see also GAREN WinTEMUTE, Ring of Fire: THe HANDGun MAKERS OF SOUTHERN CALIFORNIA 11-17 (1994).

62. Violent Crime Control and Law Enforcement Act of 1994, Pub. L. No. 103-322, 108 Stat. 1796 (1994).

63. See id. § 110102

64. See id. § 110103(b)(A).

65. See Christopher S. Koper \& Jeffrey A. Roth, The Impact of the 1994 Federal Assault Weapon Ban on Gun Violence and Outcomes, 17 J. QUAN. CRIM. 33, 36 (2001).

66. See Pub. L. No. 103-322, 108 Stat. 1796, § 110105 (1994).

67. See Vernick and Teret, supra note 49, at 1196.

68. See Richard J. BONNIE, CAROLYN FULCO \& CATHARYN T. LIVERMAN, REDUCing THE BURDEN OF INJURY: ADVANCEMENT AND TREATMENT 126 (1999).

69. The new rules effectively ban Saturday Night Specials and require that handguns sold in Massachusetts include childproof locks, tamper-proof serial numbers, and safety warnings. The new gun safety regulations affect manufacturers as well as retailers. See MASS. CODE REGS. ch. 940, § 16.01-09 (2008). 
In exchange for relieving manufacturers of small, cheap handguns from liability, the legislature created a process for reviewing handgun designs and specifying which models would be ruled out due to size and safety concerns. $^{70}$ As of 2008, eight states have some version of a ban on Saturday Night Specials ${ }^{71}$ California has also been active in recent years, instituting a ban on assault weapons and establishing a number of handgun safety requirements. $^{72}$

\section{Gun Possession and Use}

States and some localities also specify the rules under which guns may be carried in public. Every state except Vermont and Alaska places some restriction on carrying a concealed firearm. ${ }^{73}$ However, the trend over the past several decades has been to ease restrictions on concealed carry, replacing prohibition with a permit system and easing the requirements to obtain a permit. Currently, in most states adults who are entitled to possess a handgun can obtain a permit to carry after paying a fee. ${ }^{74}$

In addition, there has been some effort to regulate firearms storage. Since 2005, federal law has required all handguns sold by licensed dealers to come equipped with a secure storage device. ${ }^{75}$ As well, eleven states and the District of Columbia have laws concerning firearm locking devices. ${ }^{76}$ Massachusetts and the District require that all firearms be stored with a lock in place. $^{77}$ And the Maryland legislature recently adopted a pioneering requirement: All handguns manufactured after 2003 and sold in that state must be "personalized" with a built-in locking device that requires a key or combination to release. ${ }^{78}$

\section{4. $\quad$ Record Keeping}

Some gun regulations are designed to assist law enforcement in solving crimes. In particular, federal law requires that all licensees in the chain of commerce-manufacturers, distributors, retail dealers-keep records of

70. See Md. Pub. SAfety Code AnN. § 5-405 (2008); see also Jon S. Vernick et al., Effects of Maryland's Law Banning Saturday Night Specials on Crime Guns, 5 InJ. Prevention 259 (1999).

71. See LCAV REPORT, supra note 49, at 218.

72. See id. at 220-21.

73. See id. at 208.

74. See id. at 203; JoHn R. LOTT JR., MORE Guns, LESS CRIME: UnDERSTANDING CRIME AND GUN CONTROL LAWS 43 (2000).

75. Protection of Lawful Commerce in Arms Act, 18 U.S.C. § 922(z) (2008).

76. See LCAV REPORT, supra note 49, at xvi.

77. See id. at 226.

78. See Md. Pub. SAFETy CodE ANN. § 5-132 (2008). 
transfers and provide them to law enforcement for tracing purposes. ${ }^{79}$ For example, if a police department confiscates a firearm that may have been used in a crime, they can submit a trace request through the National Tracing Center of the Bureau of Alcohol, Tobacco, Firearms, and Explosives (ATF), which will attempt to trace the chain of commerce using the serial number and other characteristics of the gun. If all goes well, the retail dealer who first sold the gun will be identified and will supply information from the form that the buyer filled out. This system is inefficient and error-prone, and even if successful usually leaves the investigators far short of the information they really want: the identity of the most recent owner of the firearm. ${ }^{80}$ But a more direct system of national registration has been politically impossible to implement, except in the case of weapons of mass destruction. ${ }^{81}$

A few states do have registration requirements, however. California requires registration of handgun transactions, even if they occur between private parties. ${ }^{82}$ This requirement complements a new regulation that all semiautomatic pistols sold in the state after 2010 be designed with microstamp capability. Microstamping means that the firearm will print the serial number, make, and model of the gun on the shell casing when the gun is fired. ${ }^{83}$ Shell casings are ejected from pistols and often left at the scene, where they can be collected by investigators and, under the new law, used to initiate a trace even when the gun itself is not in custody.

\section{Mass Tort Litigation}

Thus far, our regulatory review shows a baseline of federal legislation with a second layer of state legislation that varies significantly across the country. In its best light, this policy diversity shouldreflect different values and circumstances in different locations. Yet much differentiation in the cost-benefit balance for gun control occurs within states, at the local level. Residents of heavily populated cities tend to suffer relatively high rates of violent crime and have little interest in gun sports, while the reverse is true in rural areas and small towns. As a result, the most extreme gun control measures tend to be adopted by cities rather than states. ${ }^{84}$ But this degree of

\footnotetext{
79. $\quad$ See 18 U.S.C. § 923(g).

80. See Cook \& Braga, supra note 26, at 301.

81. See National Firearms Act, 26 U.S.C. §§ 5801-5872 (2008).

82. See Cal. Penal Code § 12072(d).

83. See id. § 12126(b)(7).

84. See Evaluating Gun Policy 363, 367 (Jens Ludwig \& Philip J. Cook eds. 2003).
} 
decentralized policymaking is often thwarted by state law: over forty states preempt at least some local law affecting firearms. ${ }^{85}$

In the 1990s, several cities facing tremendous costs from gun-related crime tried an alternative. Frustrated by their inability to change gun regulations through legislation, they filed mass tort lawsuits that might have imposed higher standards of conduct on the gun industry. These suits asserted unsafe and defective gun design under state law, ${ }^{86}$ or claimed that the industry was creating a public nuisance through failure to police the supply chain by which guns were marketed and often found their way into dangerous hands. ${ }^{87}$ These suits were inspired by, and had parallels with, the lawsuits against the cigarette industry filed by state attorneys general. The cigarette manufacturers ultimately settled those suits, agreeing to restrictions on marketing practices and to $\$ 240$ billion in damages paid out over twentyfive years. ${ }^{88}$ One difference is that most of the plaintiffs in the gun industry suits were cities rather than states. Another difference is that the firearms industry is much smaller and more diffuse than the tobacco industry, so the financial stakes were much lower. Indeed, the primary motivation for the municipal plaintiffs was probably not money damages, but forcing the gun industry to assume greater responsibility for reducing the damage done with its products.

In any event, the cities' arguments did not fare well in court. A case brought by New Orleans, for instance, was halted by the Louisiana Supreme Court after that state's legislature enacted a statute barring such suits. ${ }^{89}$ Of the city lawsuits, the "great majority have been dismissed or abandoned prior to trial, and of the few favorable jury verdicts obtained by the plaintiffs, all but one have been overturned on appeal. A handful of claims have been settled prior to trial."90

85. See James A. Beckman, Preemption Laws, in Guns in AMERICAN SocIETY: AN ENCYCLOPEDIA OF HISTORY, POLITICS, CULTURE, AND THE LAW 478 (2002).

86. See Morial v. Smith \& Wesson Corp., 785 So. 2d 1, 5-6 (La. 2001), cert. denied, 534 U.S. 951 (2001).

87. See City of Chicago v. Beretta U.S.A. Corp., 821 N.E.2d 1099 (Ill. 2004); Brian J. Siebel, City Lawsuits Against the Gun Industry: A Roadmap for Reforming Gun Industry Misconduct, 18 ST. Louis U. PUB. L. REV. 247, $248-49$ (1999); see also Jon S. Vernick \& Stephen P. Teret, New Courtroom Strategies Regarding Firearms: Tort Litigation Against Firearm Manufacturers and Constitutional Challenges to Gun Laws, 36 Hous. L. REV. 1713, 1746-49 (1999). Thirty other cities and counties filed suits against the gun industry, claiming negligence in marketing practices, product design, or both. See generally Timothy D. Lytton, Introduction: An Overview of Lawsuits Against the Gun Industry, in SUING THE GUN INDUSTRY 1-35 (Timothy D. Lytton ed., 2005).

88. See Milo Geyelin, States Agree to \$ 206 Billion Tobacco Deal, Wall ST. J., Nov. 23, 1998, at B13.

89. See Morial, 785 So.2d at 6.

90. Lytton, supra note 87, at 5. 
Then, on October 26, 2005, President George W. Bush signed the Protection of Lawful Commerce in Arms Act (PLCAA). ${ }^{91}$ It provided an important degree of legal immunity to the firearms industry, while preserving the possibility of traditional tort actions against the industry. For example, injuries from defects in design or manufacture can be compensated in private suits. But the industry is now exempt from liability for injuries resulting from criminal misuse of its product. While PLCAA might itself be subject to constitutional challenge, ${ }^{92}$ efforts to enhance gun regulation through litigation have failed for the most part. And today the litigation opportunities are running in the opposite direction.

\section{HELLER AND THE NEXT LitigATION FRONTIER}

As of 2007, there was little else to say about the general character and dynamics of gun control policy. Certainly federal constitutional litigation was a matter of minimal significance. For most of our country's history, the Second Amendment was absent from the Supreme Court's agenda. When arguments based on the amendment reached the Court, they were ineffectual. In the late 1800s, the Court confirmed that the amendment could not be used to challenge state regulation. ${ }^{93}$ And in 1939, United States $v$. Miller ${ }^{94}$ concluded that the federal government was free to restrict possession of sawed-off shotguns. ${ }^{95}$ Miller seemed to link Second Amendment rights to state organized militias, rather than to individual preferences about gun ownership. Lower federal courts followed this notion and the amendment was a dead letter in litigation. ${ }^{96}$

Attraction to Second Amendment arguments gained strength in other contexts, however. The gun rights movement made the amendment a central rhetorical element in its organizing efforts. ${ }^{97}$ Many lawmakers were

\footnotetext{
91. $\quad 18$ U.S.C. § 922(z) (2008).

92. See Timothy D. Lytton, Afterward: Federal Gun Industry Immunity Legislation, in SUING THE GUN INDUSTRY, supra note 87, at 339-54.

93. See Presser v. Illinois, 116 U.S. 252, 264-66 (1886); United States v. Cruikshank, 92 U.S. 542, 553 (1876).

94. 307 U.S. 174 (1939).

95. See id. at 178 (seeking evidence that a sawed-off shotgun "has some reasonable relationship to the preservation or efficiency of a well regulated militia").

96. See, e.g., Gillespie v. City of Indianapolis, 185 F.3d 693, 710-11 (7th Cir. 1999), cert. denied, 528 U.S. 1116 (2000). Results from litigation involving state constitutions were not dramatically different. State supreme courts invoked state gun rights to invalidate only a few state regulations after World War II. See Adam Winkler, Scrutinizing the Second Amendment, 105 MiCH. L. REV. 683, 716-26 (2007).

97. For a view of the gun rights movement, political institutions, and Heller, see Reva B. Siegel, The Supreme Court, 2007 Term-Comment: Dead or Alive: Originalism as Popular Constitutionalism in Heller, 122 HARV. L. REV. 191 (2008).
} 
sympathetic. And by the late twentieth century, scholarship on the amendment was booming. Some legal academics supported an understanding of federal gun rights beyond anachronistic state militias. ${ }^{98}$ There were also judicial rumblings. In 1997, Justice Thomas suggested that the amendment might have provided another basis for invalidating the Brady Act's mandate that local officials conduct background checks on handgun purchasers. ${ }^{99}$ In 2001, a federal appeals court declared that the Second Amendment included a personal right to keep and bear arms unrelated to militia service, although the court upheld the regulation at issue. $^{100}$ The United States Department of Justice then amended its litigation position and endorsed the lower court's logic. ${ }^{101}$

\section{A. Heller's Demilitarized Message}

In 2008, the Supreme Court changed its message, too. District of Columbia v. Heller ${ }^{102}$ became the first successful Second Amendment challenge in the Court's history—a full 207 years after the amendment was

98. See, e.g., Sanford Levinson, The Embarrassing Second Amendment, 99 YALE L.J. 637 (1989); Robert J. Cottrol \& Raymond T. Diamond, The Second Amendment: Toward an AfroAmericanist Reconsideration, 80 GEO. L.J. 309 (1991); Randy E. Barnett \& Don B. Kates, Under Fire: The New Consensus on the Second Amendment, 45 EMORY L.J. 1139 (1996); Eugene Volokh, The Commonplace Second Amendment, 73 N.Y.U. L. REV. 793 (1998). For contrary views from historians, see SAUl CORNELl, A WELl-REgulated Militia: THE Founding FATHERS AND THE ORIGINS OF GUN CONTROL IN AMERICA (2006); Jack N. Rakove, The Second Amendment: The Highest Stage of Originalism, in THE SECOND AMENDMENT IN LAW AND HistoRY 74, 113 (Carl T. Bogus ed. 2000) ("[I]t is completely anachronistic to expect the disputants of the eighteenth century to have comprehended, much less addressed, the problem of firearms regulation in its modern form.”). On competing theories for the gist of the Amendment's meaning, see MARK V. TUSHNET, OUT OF RANGE: WHY THE CONSTITUTION CAN'T END THE BATTLE OVER GUNS (2007).

99. $\quad$ See Printz v. United States, 521 U.S. 898, 938-39 (1997) (Thomas, J., concurring) (joining the majority opinion, which relied on federalism principles, but pointing to a Second Amendment argument).

100. See United States v. Emerson, 270 F.3d 203, 260-61 (5th Cir. 2001) (upholding a conviction for gun possession while subject to a domestic violence restraining order), cert. denied, 536 U.S. 907 (2002).

101. See Memorandum from the Attorney General to All United States Attorneys Regarding United States v. Emerson (Nov. 9, 2001), available at www.usdoj.gov/ag/readingroom/emerson.htm. When Emerson sought review in the Supreme Court, the Solicitor General abandoned the militia-related view of the amendment. See Brief for the United States in Opposition to Certiorari 20 n.3, in United States v. Emerson, 536 U.S. 907 (2002) (accepting, however, "reasonable restrictions designed to prevent possession by unfit persons or to restrict the possession of types of firearms that are particularly suited to criminal misuse").

102. 118 S.Ct. 2783 (2008). 
ratified. ${ }^{103}$ This time lag between ratification and adjudication must have mattered to the decision. Because however much attention the Court's opinion paid to the circumstances of 1791, crucial features of the majority opinion bend to developments that occurred long after. At the end of the day, the opinion begins the process of accommodating an individualistic gun rights vision to the modern tradition of gun regulation.

The case involved a police officer who wanted to keep an operable handgun in his home and to "carry it about his home in that condition only when necessary for self-defense." ${ }^{104}$ But the District was an urban jurisdiction where the gun rights movement enjoyed little success in ordinary politics. One District law prohibited possession of handguns by private citizens with only narrow exceptions. ${ }^{105}$ A second regulation required all firearms to be either unloaded and disassembled or triggerlocked at all times. ${ }^{106}$ Exceptions were made for law enforcement officers, places of business, and otherwise lawful recreational activities, ${ }^{107}$ but the regulation reached people's homes. A third regulation involved firearms licensing by the chief of police. ${ }^{108}$ The Heller majority left unaddressed the issue of firearms licensing, but it concluded that the first two regulations infringed this plaintiff's right to have a handgun in his home for selfdefense. $^{109}$

It is quite possible to read the majority opinion for very little. The justices did not commit to restraining state or local firearms laws, ${ }^{110}$ which is where much of the regulatory action takes place. Furthermore, the plaintiff's position in Heller was relatively strong. The regulations under attack were fairly broad; the argument came down to a qualified right to handgun possession in the home, and the dissenting justices thought the amendment was not even implicated without a militia connection. ${ }^{111}$ Even under these circumstances, the gun rights position only narrowly prevailed on a 5-4 vote. Perhaps a slightly different case would fracture the majority coalition. After all, it does not take special courage to oppose flat handgun bans. ${ }^{112}$ One can at least imagine the 5-4 vote going the other way had the

103. For an analysis of such time lags, see Adam M. Samaha, Originalism's Expiration Date, 30 CARDOZO L. REV. (forthcoming 2008) (manuscript at 17) (estimating the average lag between formal amendment and Supreme Court interpretation at forty years).

104. Heller, 118 S.Ct. at 2788 \& n.2 (relating the lower court's understanding).

105. See D.C. Code $\S 7-2502.01$.

106. See id. § 7-2502.02.

107. See id.

108 See id. § 22-4506.

109. See Heller, 118 S.Ct. at 2819 (regarding licensing).

110. See id. at 2812-13 \& n. 23.

111. See id. at 2823, 2847.

112. See supra notes 3-4 (citing polling and majority congressional opposition to flat handgun bans). There is a large empirical literature on the determinants of judicial behavior which 
District permitted a law-abiding citizen to store one handgun in the home, but required handgun training, registration, and a trigger lock-except when and if self-defense became necessary. ${ }^{113}$

Nevertheless, more significant lessons might be drawn. The first notable feature of the majority opinion is the virtual irrelevance of militias to its view of gun rights. The text of the Second Amendment begins with the preface, "A well regulated Militia, being necessary to the security of a free State, ...." Whether or not this assertion is factually accurate, it could serve an important role in understanding the words that follow: "the right of the people to keep and bear Arms, shall not be infringed." But for the majority, the amendment's preface cannot be used to either limit or expand the meaning of the subsequent words when read separately. ${ }^{114}$ Instead, the militia reference is supposed to indicate the purpose for codifying a preexisting right of "the people" in general to keep and bear arms. ${ }^{115}$ Although the amendment's ratification did follow a debate over standing armies and the ability of state militias to check centralized tyranny, the Heller majority contended that the codified right to keep and bear arms also was valued for self-defense. ${ }^{116}$ This more personal self-defense function, not the prerequisites of a robust citizen militia, defines the scope of the right in Heller.

Fencing off the amendment's judicially enforceable right from its militia-oriented preface is revealing - and it cuts in two directions. Some of the implications point toward judicial intervention. Private parties are now allowed to raise Second Amendment arguments in court without showing any relationship to a militia, state-run or otherwise. The content of the right is personal and nonmilitary. As well, incorporation of Second Amendment norms into the Fourteenth Amendment might seem easier once the content of the former is separated from the preservation of state militias. If the right is not about federal-state relations, it better resembles the individual rights

we will not delve into here. See, e.g., Barry Friedman, The Politics of Judicial Review, 84 TEX. L. REV. 257 (2005). The classic view of the Court as sticking close to national governing coalitions is Robert A. Dahl, Decision-Making in a Democracy: The Supreme Court as a National PolicyMaker, 6 J. PuB. L. 279 (1957).

113. For a discussion of the District's first temporary legislative reaction to Heller, which allowed registration of handguns (excluding semi-automatics) for in-home self-defense (after a ballistics test) and allowed trigger locks to be removed when the owner reasonably feared imminent harm in the home, see Del Quentin Wilber \& Paul Duggan, D.C. Is Sued Again Over Handgun Rules, WASH. Post, July 29, 2008, at B01. The District's second round of temporary legislation can be found at Second Firearms Control Emergency Act of 2008, available at http://mpdc.dc.gov/mpdc/frames.asp?doc=/mpdc/lib/mpdc/info/pdf/2ndFirearmsControl_Act.pdf.

114. See Heller, 128 S.Ct. at 2792-97 \& nn. 3-4.

115. See id. at 2800-02.

116 See id. at 2817-18. 
the Court has been willing to enforce against state and local governments through the Fourteenth Amendment. ${ }^{117}$

But another implication involves judicial restraint. Ignoring the practical needs of decentralized citizen militias allows courts to reject libertarian demands for exceptionally potent firepower and to preserve the modern role of government in law enforcement and national defense. The Heller majority is not about to enforce any asserted right to frighten the United States Armed Forces with overwhelming firepower. The majority's portrayal of the Second Amendment right seems, at most, tangentially related to people protecting themselves from the risks of centralized tyranny. ${ }^{118}$ Instead, the majority's conception of the right is mainstreamed and demilitarized. In this respect, one can say that Heller defanged the Second Amendment for litigation purposes.

\section{B. Heller's Core Right and Suggested Limits}

What, then, is the judicially enforceable right recognized in Heller? The answer is debatable. Different readers will see the matter differently in the absence of additional direction from the justices regarding what they meant (or mean) to do. To make progress, however, we can look for Heller's minimum plausible content. We can attempt to describe the core right to which a majority of justices seem clearly committed.

Whatever else it might be made to include, the majority's core right involves self-defense with a typical handgun in one's home. These justices were not interested in a right to carry arms "for any sort of confrontation,"119 and declared that "self-defense ... was the central component of the right" codified in the amendment. ${ }^{120}$ And in explaining why the District's handgun ban was defective, the majority stressed the confluence of three factors: selfdefense, handguns, and homes. It asserted that an inherent right of selfdefense has been central to the understanding of the Second Amendment in American history, that handguns are now commonly chosen by Americans for lawful self-defense, and that people's homes are where "the need for defense of self, family, and property is most acute.”121 For similar reasons, the majority immunized the plaintiff's handgun from the District's requirement that firearms in the home be kept inoperable at all times. ${ }^{122}$

117. See generally ERWIN CHEMERINSKY, CONSTITUTIONAL LAW: PRINCIPLES AND PREMISES 499-507 (3d ed. 2006) (reviewing selective incorporation).

118. See Heller, 128 S.Ct. at 2817.

119. Id. at 2799 .

120. Id. at 2801.

121. Id. at 2817.

122. See id. at 2818 (referring to "the core lawful purpose" of self-defense). 
Hence the majority's core conception of the right seems to contemplate a law-abiding citizen with a functional handgun in his own home for the purpose of defending it, and perhaps only at the time of attack. ${ }^{123}$ This notion of the right was strong enough to overcome an outright prohibition on possessing a functional handgun in one's own home at any time. And this description of the right matches the situation of the actual plaintiff in Heller, who asked to store an operable handgun in his home and to carry it there only when necessary for self-defense.

In fact, limits were a theme in the majority opinion. These justices went out of their way to suggest insulation for several forms of gun control not at issue in the case. They conceded that the Second Amendment right is "not unlimited," "124 and offered a list of "presumptively lawful regulatory measures." 125 In crude terms, this nonexhaustive list includes regulation aimed at (1) atypical weapons, (2) abnormal people, (3) sensitive locations, (4) sales conditions, (5) safe storage, and, perhaps, (6) concealed carry. Although the matter is not free from doubt, it appears that these presumptively valid regulations would withstand a Second Amendment objection even to the extent that they apply to handgun possession in the home for self-defense. Otherwise Heller's core right would seem "unlimited" in ways that the majority did not mean.

Thus the majority sought to protect weapons "typically possessed by law-abiding citizens" for self-defense in the home, ${ }^{126}$ asserting that a limitation to weapons in common use is consistent with a tradition of restricting "dangerous and unusual weapons."127 Handguns are thereby covered in view of their current popularity in the market, ${ }^{128}$ while the majority strongly suggested that machine guns, M-16s, and sawed-off shotguns are not. ${ }^{129}$ We do not know the extent to which regulation may validly influence which weapons become common. Such influence was implicitly tolerated by the Heller majority because the mix of weapons purchased in contemporary America is partly a function of the tax and regulatory policies discussed in Part I. In any event, a right restricted to the type of weapon owned by the mainstream of armed home-defenders fits with the majority's demilitarized vision of the amendment.

The discussion of other presumptively valid regulation was even more brief: "nothing in our opinion should be taken to cast doubt on longstanding

See id. at 2788, 2822.

Id. at 2816.

Id. at 2817 \& n. 26.

Id. at 2815-18 (emphasis added).

See id. at 2817.

See id. at 2818.

See id. at 2815, 2817. 
prohibitions on the possession of firearms by felons and the mentally ill, or laws forbidding the carrying of firearms in sensitive places such as schools and government buildings, or laws imposing conditions and qualifications on the commercial sale of arms." ${ }^{\text {"130 }}$ Later, in distinguishing founding era regulation of gun powder storage, the majority said its logic did not suggest problems with "laws regulating the storage of firearms to prevent accidents.”131 Finally, the majority observed that most nineteenth-century cases had upheld prohibitions on concealed weapons. ${ }^{132}$

The opinion is, nevertheless, a litigation magnet. On the same day that Heller was decided, suit was filed against the city of Chicago arguing that the Heller right must be enforced against state and local action. ${ }^{133}$ In another suit raising the incorporation question, gun show owners are using Heller to challenge Alameda County's law against guns on county property. ${ }^{134}$ And New York City is now defending its handgun permit system, which critics argue is too demanding and grants excessive discretion to the police department. ${ }^{135}$ Some criminal defendants are even objecting to the federal machine gun ban and felon in possession convictions, despite the list of presumptively valid regulations in Heller. ${ }^{136}$ And some jurisdictions are avoiding the costs and risks of litigation by repealing their handgun bans without a fight over incorporation. ${ }^{137}$ In early 2009, San Francisco followed

130. Id. at $2816-17$.

131. Id. at 2820 .

132. See id. at 2816. On unconcealed pistols, see Part III.C, below.

133. The Second Amendment Foundation maintains a website dedicated to the case: www.chicagoguncase.com. Plaintiffs are challenging Chicago's handgun ban, see CHICAGO MUNI. CODE §§ 8-20-040(a),-050(c) (noting exceptions), as well as the city's requirement that firearms be registered before acquisition and then re-registered annually, see id. §§ 8-20-090(a),200. However, Chicago law seems to differ from the District of Columbia's regime at issue in Heller, in that Chicago does not appear to mandate a trigger lock on all firearms in the home at all times. Whether any such difference will influence litigation outcomes remains to be seen.

134. The case, Nordyke v. King, is pending in the Ninth Circuit as of this writing. The oral argument is available at http://www.cspanarchives.org/library/index.php?main_page=product_video_info\&cPath=18_19\&products_id= 283468-2\&highlight $=$.

135. See Daniel Wise, Defense Lawyers Fire First Shot in Challenge to State Gun Law, N.Y. L.J., vol. 240, July 16, 2008, at1.

136. These arguments have not been successful in lower federal courts, however. See, e.g., United States v. Gilbert, 286 Fed. Appx. 383, 2008 WL 2740453, at *2 (9th Cir. July 15, 2008) (unpublished disposition), cert. denied, 129 S.Ct. 613 (2008); United States v. Whisnant, 2008 WL 4500118, at *1 (E.D. Tenn. Sept. 30, 2008) (No. 3:07-CR-32) (collecting cases); see also Adam Winkler, Heller's Catch-22, 56 UCLA L. REV. __ _-_ (2009) (manuscript at 14-17) (analyzing post-Heller lower court cases).

137. See Deborah Horan, Evanston Latest Suburb to Repeal Handgun Ban in Wake of High Court Ruling, CHICAGO TRIB., Aug. 12, 2008, available at www.chicagotribune.com/news/local/chi-gun-ban_13aug13,0,1421061.story. Prevailing plaintiffs may recover their attorneys fees from state and local defendants in federal constitutional litigation, 
this course. It settled a gun rights lawsuit by agreeing to eliminate a lease provision for public housing tenants that prohibited storage of firearms and ammunition. ${ }^{138}$ The question is how the legal uncertainty will shake out.

\section{Models for Judicial Review After Heller}

Even with the majority's laundry list of presumptively valid regulations in hand, there is no obvious theory by which to better specify the listed items or to add new items. Remember that the list is neither conclusive nor exhaustive. Is the list governed by historical analogies and traditional police powers? Can it be built into a general principle allowing "reasonable" regulation? This is unsettled. Nor did the majority identify a generic test that one should apply to determine whether the Second Amendment is violated. Providing such guidance is not a requirement for case law and it can be difficult to do well in a single decision, but the absence of a prescribed test leaves regulators guessing.

One possibility is that the Court will fashion additional rules based on history and analogy. After all, the Heller majority devoted thousands of words to an analysis of historical sources. These justices indicated that they were investigating the ordinary meaning of the amendment's words to ordinary citizens in $1791 .^{139}$ Whatever version of originalism was on display, it was the predominant mode of argument for the majority. In addition, the majority rejected case-by-case balancing of competing interests within the perceived "core protection" of the Second Amendment. ${ }^{140}$ In contrast, Justice Breyer's dissent advocated judicial balancing and considered much more than founding-era firearms regulation. ${ }^{141}$ The majority responded, "whatever else [the amendment] leaves to future evaluation, it surely elevates above all other interests the right of lawabiding, responsible citizens to use arms in defense of hearth and home."142

but prevailing defendants normally cannot. See HAROLD S. LEWIS, JR. \& ELIZABETH NORMAN, CiVIL RighTS LAW AND PRACTICE 442-64 (2001).

138. See Stipulation Regarding Settlement and Dismissal, Doe v. San Francisco Housing Auth., Case No. CV-08-03112 TEH (N.D. Cal. Jan. 12, 2009) (continuing to prohibit unlawful firearms and ammunition possession), available at http://volokh.com/files/sfpublichousingguns.pdf.

139. See Heller, 128 S.Ct. at 2788, 2810. On different versions of originalism, see Samaha, supra note 103, at 35-37.

140. Heller, 128 S.Ct. at 2821.

141. See id. at 2847-68 (Breyer, J., dissenting).

142. Id. at 2821; see also id. ("Constitutional rights are enshrined with the scope they were understood to have when the people adopted them....”). Of course a right's originally understood scope, to the extent that any such meaning was determinate within the relevant population at the relevant time, could include consideration of circumstances that may change and authorization of future decision makers to adjust in light of those changes. 
There is no hint here of judges asking whether a challenged regulation is justified by cost-benefit analysis or supported by reliable data.

But other facets of Heller indicate the Court is not locked into strong and rule-oriented originalism. As for hard-line rules over flexible standards, the majority's repudiation of case-specific interest balancing was done with reference to the "core protection" recognized in Heller. ${ }^{143}$ Perhaps the majority's inflexibility begins and ends with this core right, while some brand of judicial cost-benefit analysis would be appropriate elsewhere, at least at the periphery of Second Amendment values. As for originalism, it was not the only form of analysis on display. Founding-era historical sources were not used and probably cannot explain certain critical junctures in the majority opinion.

Most notably, the majority's list of presumptively valid firearms regulation was not supported with serious originalist investigation. In fact, the list was not supported with much of any argument. It is quickly becoming one of the most important features in the majority opinion, yet its foundation is far easier to locate in contemporary political consensus or perhaps the necessity of pragmatic compromise in building a five-vote coalition on the bench than it is to support with eighteenth-century regulatory examples. Equally important, the majority relied on sources far removed from 1791. Heller's rendition of nineteenth-century characterizations of the Second Amendment stretched to include sources postdating ratification by nearly 100 years. ${ }^{144}$ These citations help us understand postenactment traditions much better than they can reveal any settled meaning at the founding. Using tradition to inform constitutional doctrine is also consistent with the majority's reference to "longstanding" gun control in its preferred list, ${ }^{145}$ with its claim that the District's ban was more burdensome than others in history, ${ }^{146}$ and with its reliance on an extended practice of prohibiting unusual weapons. ${ }^{147}$ While such analysis does involve history and analogy, it is a departure from strong and pure originalism.

Judge-centered traditions played a role in the majority opinion as well. For example, the majority claimed that the District's handgun ban flunked "any of the standards of scrutiny that we [judges] have applied to enumerated constitutional rights." 148 But no one asserts that these standards are dictated by originalism alone. They are tests that courts developed to

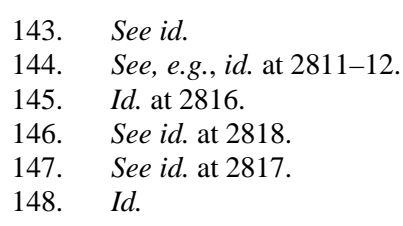


implement constitutional norms. ${ }^{149}$ The majority also made the effort to reconcile their historical conclusions with the Court's meager case law regarding the Second Amendment, ${ }^{150}$ which was unnecessary if only originalist history mattered. And the majority cautioned that nineteenthcentury precedent indicating that gun rights are not enforceable against state action "did not engage in the sort of Fourteenth Amendment inquiry required by our later cases." 151 Hence neither strong originalism nor strict rule-like doctrine have been locked into place by Heller-surely not in the long run, possibly not for cases outside of the core right now recognized, and perhaps not for the process of defining limits on that core right. Only by word count is the Heller opinion dominated by originalism.

If we are correct, then the majority exhibited dependence on history without prescribing any particular model for judicial review of Second Amendment claims over the long term. And there is no consensus model that judges could import from other fields of constitutional adjudication. The truth is that judicial review is not a binary choice. Turning it on does not determine exactly how it should be performed. Instead, making judicial review operational requires choices along several dimensions, and it implicates fundamental questions about the judicial role.

The first choice is whether any judicial oversight will take place. Some clauses of the written Constitution are never litigated (for example, many provisions involving the structure of Congress) or are not enforced by courts (for example, certain issues of impeachment). ${ }^{152}$ Some clauses were enforced against ordinary politics in one era only to be largely ignored in another (for example, the Contracts Clause). ${ }^{153}$

Among those constitutional norms that courts are comfortable enforcing, judges have developed a variety of practices. Some domains are filled with founding-era history and analogical reasoning (for example, federal jury trial rights). ${ }^{154}$ Other domains turn to longstanding tradition for guidance (for example, strands of substantive due process). ${ }^{155}$ Many others are dominated by judicial precedent and analogical reasoning (for example,

149. For a catalog of doctrinal tests developed by courts in constitutional cases, see RICHARD H. FALLON, JR., IMPLEMENTING THE CONSTITUTION (2001).

150. See Heller, 128 S.Ct. at 2808-09.

151. Id. at 2813 n. 23; see also id. at 2791 ("Some have made the argument, bordering on the frivolous, that only those arms in existence in the 18th century are protected by the Second Amendment. We do not interpret constitutional rights that way.”).

152. See, e.g., Nixon v. United States, 506 U.S. 224 (1993).

153. See Adam M. Samaha, Dead Hand Arguments and Constitutional Interpretation, 108 COLUM. L. REV. 606, 642 (2008).

154. See, e.g., Curtis v. Loether, 415 U.S. 189, 193 (1974).

155. See, e.g., Washington v. Glucksberg, 521 U.S. 702, 720-22 (1997). 
speech and abortion rights). ${ }^{156}$ Some combine precedent, originalist history, and contemporary interest balancing (for example, search and seizure jurisprudence). ${ }^{157}$

Even when common law development of constitutional doctrine predominates, diversity reappears. Some justices value specific doctrinal rules over the flexibility of more open-ended standards, while others exhibit the opposite preference. ${ }^{158}$ The intensity of judicial review also varies. Sometimes the Court organizes its thinking around several tiers of scrutiny (for example, equal protection doctrine). These tiers vary in how important the asserted regulatory interest must be and how tightly connected that interest must be to the regulation under attack. Presumptively invalid regulatory classifications, such as race, receive nondeferential strict scrutiny; ${ }^{159}$ a few others, including sex, receive intermediate scrutiny; ${ }^{160}$ mere rational basis review with extreme deference to policymakers is applied elsewhere. ${ }^{161}$ Much free speech precedent has a similar character. ${ }^{162}$ But in other fields, this analytical structure is not apparent. In Eighth Amendment cases, the Court looks to policy trends across the country and then exercises its own judgment on whether the punishment in question is cruel under contemporary standards of decency. ${ }^{163}$

Whatever shape Second Amendment doctrine takes in this expanse of options, the country's experience with judicial review does suggest boundaries on its influence. First, judicial review cannot be fully detached from politics. If nothing else, the appointments process connects judicial personnel to organized interests and elected officials. The course of Second Amendment litigation depends, in part, on who will judge these cases in the future.

156. See Davis v. FEC, 128 S.Ct. 2759 (2008) (invalidating a campaign finance regulation by relying on free speech case law and not originalist history). Davis was issued on the same day as Heller and was decided by the same $5-4$ coalitions. The leading expositor of common law constitutionalism is David A. Strauss, Common Law Constitutional Interpretation, 63 U. CHI. L. REV. 877 (1996).

157. See, e.g., Wyoming v. Houghton, 526 U.S. 295, 299-300, 303 (1999).

158. See Kathleen M. Sullivan, The Supreme Court, 1991 Term-Foreword: The Justices of Rules and Standards, 106 HARV. L. REV. 22 (1992). Compare the Court's general balancing test for due process violations, which is a form of cost-benefit analysis, see Mathews v. Eldridge, 424 U.S. 319, 332-35 (1976), and its "undue burden" test in abortion cases, see Planned Parenthood v. Casey, 505 U.S. 833, 869-79 (1992) (joint opinion), with its rulings in some federalism cases, which may promote more specific rules such as a prohibition on "commandeering" state officers, see Printz v. United States, 521 U.S. 898 (1997).

159. See, e.g., Grutter v. Bollinger, 539 U.S. 306, 326-27 (2003).

160. See, e.g., Mississippi Univ. for Women v. Hogan, 458 U.S. 718, $723-24$ (1982).

161. See, e.g., Cleburne v. Cleburne Living Ctr., 473 U.S. 432, 440 (1985).

162. See infra Part III.D.

163. Justice Kennedy did so for the Court last Term. See Kennedy v. Louisiana, 128 S.Ct. 2641 (2008) (invalidating the death penalty for child rape). 
Second and related, the federal judiciary does not have an impressive track record in making major policy change. ${ }^{164}$ Judges might resist the intense policy preferences of others for a time, but courts are not insulated in the long run. Thus the Supreme Court could not effectively desegregate public schools alone, and it did not resist New Deal innovations forever. It bears repeating that the gun rights movement began outside the courtroom, and that handgun bans were already quite unpopular at the national level. As should be apparent from our discussion in Part I, Heller stepped into an existing regulatory and political structure built up over many years. It did not discard that structure entirely. The Revolution might well be televised, but it almost certainly will not be litigated.

We might then predict that Second Amendment litigation will probably dampen regulatory diversity to some degree, without eliminating existing gun control within the political mainstream. ${ }^{165}$ Surely the short-term impact of Heller is a reduction in policy variation by eroding the most assertive end of the regulatory spectrum. If the case is extended to state and local law, this effect could be more serious. Local outliers will not be able to sustain every local preference for strict gun control based on local conditions.

\section{ON THREATS AND SidESHOWS TO SOCIAL WELFARE}

Heller establishes a limited core right to handgun possession in the home without necessarily meaning more. Courts could push further, and they have models for relatively assertive judicial review in other fields. But we doubt that constitutional litigation will radically change the character of firearms regulation in the United States. There are few if any examples of judicial power effectively implementing major social change. Courts tend to work at the margins of public policy, and Heller does not commit the Supreme Court to a more assertive mission. That said, courts could use the Second Amendment to shape the future of gun control policy in significant ways.

Our aim here is to speculate about the path of Second Amendment litigation to come. We attempt to identify issues that plausibly could be litigated and that could make a serious difference to social welfare based on current knowledge. It turns out that some hot topics destined for judicial resolution are of little or uncertain significance to sound and effective

164. See, e.g., NEIL K. KOMESAR, IMPERFECT ALteRnATIVES: CHOOSING INSTITUTIONS IN LAW, ECONOMICS, AND PUBLIC POLICY 123, 251 (1994) (noting that courts can address only a small fraction of significant policy disputes); GERALD N. ROSENBERG, THE HOLLOW HOPE: CAN COURTS BRING ABOUT SOCIAL CHANGE? (2d ed. 2008).

165. A similar view is defended in Cass R. Sunstein, Second Amendment Minimalism: Heller as Griswold, 122 HARV. L. REV. 246 (2008). 
regulation of firearms, while possibly unappreciated constitutional arguments pose real concerns for social welfare over the longer term.

We begin with a short discussion of incorporation and an inquiry into whether the elimination of municipal handgun bans is truly a matter of major concern. We ask the same question regarding the looming litigation contest over a right to carry handguns in public. Then we turn to potential challenges to firearms laws that give us greater pause: attacks on a variety of laws and practices that treat guns as a special category, including excise taxes on firearms, gun design regulation, and even gun-oriented policing. Finally, we address the somewhat cloudy relationship between gun rights litigation and regulatory innovation.

\section{A. Incorporation}

Incorporation of Second Amendment norms against state and municipal action has become a highly salient legal issue after Heller. The Court's majority mentioned the question, ${ }^{166}$ and the city of Chicago is currently resisting incorporation in a lawsuit that challenges its handgun ban. ${ }^{167}$ It is a virtual certainty that the Supreme Court will confront the incorporation issue in the near future.

The significance of incorporation, however, is open to a measure of debate. Clearly a judicial refusal to enforce Second Amendment norms against state or local regulation would seriously undercut any practical importance of Heller and its progeny. The federal government has not been the principal source of gun control. The political environment has been such that aggressive gun control efforts tend to occur in a select set of states and cities; the absence of incorporation would leave those jurisdictions untouched by Second Amendment litigation. ${ }^{168}$

The question is whether a judicial decision in favor of incorporation would have much greater consequences. But we cannot answer without knowing how Second Amendment doctrine itself will develop. If Heller is interpreted narrowly — only flat handgun prohibitions are declared invalid-

166. See Heller, 128 S.Ct. at 2813 n. 23.

167. See supra note 133.

168. One caveat is the possibility that state courts' understanding of state constitutional gun rights could be influenced by the Supreme Court's understanding of the Second Amendment, regardless of incorporation, and that the latter understanding could turn out to be expansive. Assessing the likelihood of this possibility is difficult. It is plainly not a foregone conclusion, even if the Supreme Court does take an expansive view of the amendment. Formal legal logic does not require this result, but $c f$. FLA. CONST. art. 1, § 12 (adopted 1982) (linking state search and seizure guarantees to U.S. Supreme Court doctrine), and state courts applying state constitutional law sometimes explicitly reject Supreme Court elaboration of federal constitutional law as a model, see, e.g., State v. Parker, 987 P.2d 73, 77-78 \& nn. 1-2 (Wash. 1999) (involving searches). 
then the impact on gun policy will not be dramatic regardless of whether states and municipalities are subject to suit. ${ }^{169}$ Of course judicial doctrine on gun rights easily could become more assertive than that, and the mere threat of litigation can influence policymaking. But the potential impact of incorporation heavily depends on the as-yet unsettled content of Second Amendment doctrine.

In any event, a fair guess is that the Heller majority is poised to incorporate. Those five justices reserved the issue, but they gratuitously observed that nineteenth-century precedents insulating state action had not employed the Court's more recent approach to incorporation. ${ }^{170}$ In addition, the majority's rendering of the Second Amendment right was emphatically personal. This makes it difficult to resist application against the states with an argument that the amendment was written to protect the militias of those same states. Moreover, the majority's discussion of Reconstruction Era sources indicates a belief that those involved in creating the Fourteenth Amendment were concerned about the gun rights of freed slaves. ${ }^{171}$ This version of history would allow the Court to link gun rights to an antisubordination effort very different from another strut in the individual rights heritage: Dred Scott v. Sandford. ${ }^{172}$ In addition, if the question is whether the right is sufficiently "fundamental" to warrant enforcement against all levels of government, ${ }^{173}$ the Heller opinion intimates an affirmative answer. ${ }^{174}$

Finally, the Court could incorporate without totally repudiating Presser v. Illinois, ${ }^{175}$ a key precedent in this area. That case rejected a gun rights claim under the Second and Fourteenth Amendments, but it involved state restrictions on unauthorized military organizations parading as such. ${ }^{176}$ This claim is far different from the demilitarized vision of gun rights endorsed in

169. See also infra Part III.B (discussing the limited importance of handgun bans).

170. See Heller, 128 S.Ct. at 2813 n. 23.

171. See id. at 2809-11.

172. 60 U.S. (19 How.) 393, 450 (1857) (opinion of Taney, C.J.) (dictum) (referring to the right to keep and bear arms in a list of unconstitutional federal "powers ... . in relation to rights of person”), quoted in Parker v. District of Columbia, 478 F.3d 370, 391 (D.C. Cir. 2007), aff'd sub nom., Heller v. District of Columbia, 128 S.Ct. 2783 (2008).

173. Duncan v. Louisiana, 391 U.S. 145, 148-49 (1968) (regarding jury trial rights in criminal cases). Note that the plaintiffs in the Chicago litigation are asking the courts to reconsider the narrow understanding of the Fourteenth Amendment's Privileges or Immunities Clause in Slaughter-House Cases, 83 U.S. (16 Wall.) 36 (1873), in addition to arguing for incorporation under the Due Process Clause of the Fourteenth Amendment. See Plaintiffs' Motion to Narrow Legal Issues 4-5, in McDonald v. City of Chicago, No. 08-CV-3645 (Oct. 21, 2008), available at http://www.chicagoguncase.com/wp-content/uploads/2008/10/motionnarrowlegalissues.pdf.

174. Cf. Heller, 128 S.Ct. at 2798 ("By the time of the founding, the right to have arms had become fundamental for English subjects.”).

175. 116 U.S. 252 (1886).

176. See id. at 264-66. 
Heller. It seems that Presser comes out the same way under Heller regardless of the Court's position on incorporation-which is another reminder that the stakes of incorporation depend on the substance of the right to be enforced.

We cannot know with certainty how today's justices will respond to arguments on incorporation, a topic that the Court has not often confronted in recent decades and that implicates critical judicial choices concerning federalism and constitutional jurisprudence more generally. But we can still conjecture as to the plausible substance and impact of Second Amendment rights after Heller, assuming that incorporation will happen.

\section{B. Handgun Bans}

Heller establishes that the current Supreme Court will not tolerate comprehensive handgun bans when such laws are challenged by citizens that the Court believes are otherwise entitled to possess handguns for the purpose of self-defense in the home. The question for us is whether this judicial commitment matters much, even if it applies against state and local action and not only the federal government and its enclaves. There are at least two perspectives from which to respond. The first is political, in that it considers the viability of proposed handgun bans among policymakers. The second perspective involves policy consequences, in that it assumes the enactment of handgun bans and considers their potential influence on social welfare. As far as we can discern from the available evidence, neither perspective does much to establish the impact of handgun bans on social welfare in the United States.

\section{A Political Perspective}

Of all the forms that gun control takes in America, comprehensive handgun bans are among the least popular. This policy has never been an element of federal law or, it seems, a realistic proposal at the national level. A handful of municipalities have enacted handgun prohibitions, among them are the major metropolises of Chicago and the District of Columbia. But these locations and their political settings are fairly unique. It is possible that the center of political gravity in other localities is such that handgun bans would be enacted but for state-level politics that prevents them. Most states now have preemption legislation or precedent that allocates 
lawmaking authority over firearms to state legislatures rather than city councils. ${ }^{177}$

Of course, if handguns bans were generally popular, then elevating the level for gun control policymaking from cities to states would not necessarily lead to less territory being covered by such bans. But they are not popular, at least according to recent public opinion polling. In a 2007 Gallup Poll, sixty-eight percent of respondents opposed a handgun ban. ${ }^{178}$ Opposition reached across several demographic categories. Respondents with postgraduate education expressed opposition at a sixty percent level, and fifty-seven percent of women over age fifty were also opposed. ${ }^{179}$ It is worth emphasizing that litigation threats are an unlikely explanation for the rarity of handgun bans. Until 2008, Second Amendment arguments were ineffectual in courts, and state constitutional adjudication was not radically more inhibiting. ${ }^{180}$ Handgun bans have been unpopular with policymakers for other reasons. From what we can gather, the political resistance to handgun bans is not the result of a well-organized gun rights minority blocking the preferences of a dispersed majority. This public choice story might fit the resistance to other gun-control proposals — some of which show national majority support in polling ${ }^{181}$-but it is probably a weak explanation for the rarity of handgun prohibitions. ${ }^{182}$

There is a notable qualification here, however. Political environments are not stable over the long term and so there is no guarantee that popular preferences regarding handgun regulation are fixed. Demand for more aggressive legislation in urban areas could develop over time, at least in the absence of serious litigation threats. ${ }^{183}$ Constitutional litigation has the potential to inhibit those political changes, certainly at the margins and

177. See, e.g., Sippel v. Nelder, 101 Cal. Rptr. 89 (Ct. App. 1972) (invalidating a San Francisco handgun permitting system in favor of state law); Beckman, supra note 85, at 478.

178. See Gallup POll Social SeRIES: Crime (Oct. 4-7, 2007) (question 21)

179. See id at 252. See also Sunstein, supra note 165, at 252 (asserting that "national opposition to a ban on handguns has been larger and more consistent in recent years").

180. See, e.g., Quilici v. Village of Morton Grove, 695 F.2d 261 (7th Cir. 1982) (upholding a local operative handgun ban against state constitutional, Second Amendment, and Ninth Amendment claims), cert. denied, 464 U.S. 863 (1983); Kalodimos v. Village of Morton Grove, 470 N.E.2d 266 (Ill. 1984) (rejecting a claim under a qualified state constitutional right to keep and bear arms).

181. See SMITH, supra note 15 , at 1 (showing support for a variety of gun regulations).

182. However, we cannot rule out the possibility that there is an unorganized majority in some states that would prefer greater decentralization in gun control policymaking but that is blocked by a better organized gun rights movement.

183. The Village of Morton Grove, which apparently enacted the first comprehensive municipal handgun prohibition, repealed its law after opponents filed suit in the wake of Heller. See Robert Channick, Morton Grove Repeals 27-Year-Old Gun Ban, CHI. TRIB., July 28, 2008 ("Fighting in court to try to keep the law would cost money the village does not have, officials said.”). 
possibly beyond. For some observers, this lock-in effect is desirable. But regardless of one's ideological predispositions on firearms regulation, Heller and its incorporation against municipal action might be important insofar as courts could drive a wedge between emerging political preferences and valid law. We discuss the chilling effects on policy innovation below.

\section{A Policy Consequence Perspective}

Even if judicial doctrine ultimately stands against handgun bans enacted by any level of government, one can ask whether these formal laws have much impact on social welfare. An effective judicial campaign to eliminate certain types of legislation is not necessarily a matter of serious concern if the targeted legislation is ineffectual. If, however, such legislation tends to reduce the prevalence of handgun ownership by raising the costs of acquisition, even if acquisition remains possible, then the question becomes how handgun ownership is related to crime and public health. There has been considerable research on this relationship.

\section{a. Gun Prevalence, Crime, and Public Health}

Firearms are the most lethal of the widely available weapons deployed in assaults, robberies, and self-defense. They are the great equalizer. With a gun, most anyone can threaten or inflict grave injury on another, even someone with greater skill, strength and determination. With a gun, unlike a knife, one individual can kill another quickly, at a distance, on impulse.

The logical and documented result is that, when a gun is present in an assault or robbery, the victim is more likely to die. It is not only the assailant's intent that determines the outcome, but also the means of attack. This conclusion regarding instrumentality has been demonstrated in a variety of ways and is no longer controversial among social scientists. ${ }^{184}$ Thus widespread gun use in violent crime intensifies violence, increasing the case-fatality rate. The United States is exceptional with respect to violent crime not because we have so much more of it, but because widespread gun availability and use means that our violence is so much more deadly than other Western nations. ${ }^{185}$

184. See Franklin E. Zimring, The Medium Is the Message: Firearm Calibre as a Determinant of Death From Assault, 1 J.L. STUDIES 97 (1972); Franklin E. Zimring, Is Gun Control Likely to Reduce Violent Killings?, 35 U. CHI. L. REV. 21 (1968); Cook, supra note 11, at 18-19; William Wells \& Julie Horney, Weapon Effects and Individual Intent to Do Harm: Influences on the Escalation of Violence, 40 CRIMINOLOGY 265 (2002).

185. See Franklin E. ZimRING \& Gordon Hawkins, CRIME Is Not the PRoblem: LETHAL VIOLENCE IN AMERICA 52 (1997) (comparing the United States with other developed nations in terms of life-threatening and other violence). 
The likelihood that a gun will be used in crime is closely linked to the general availability of guns, and especially handguns. In jurisdictions where handgun ownership is common, the various types of transactions by which youths and criminals become armed are facilitated. The list of transactions includes thefts from homes and vehicles, loans to family members and friends, and off-the-books sales. In a high-prevalence area, then, transactions in the secondary market are subject to less friction and may well be cheaper than in markets where gun ownership is rare. ${ }^{186}$ While there is no evidence that gun prevalence affects the rate of violent crime, gun prevalence does have a demonstrable effect on the likelihood that the assailants in robbery and assault will be armed with guns, resulting in a higher case-fatality rate than would otherwise occur.187

Research on the effects of gun prevalence has been facilitated by the discovery of a useful proxy: the percentage of suicides committed with guns. ${ }^{188}$ It allows us to analyze how gun use relates to the prevalence of gun ownership across states or even counties. This proxy has been used to document a strong positive relationship between county gun prevalence and each of the following outcomes: the fraction of robberies involving guns, the fraction of homicides with guns, the likelihood that young men carry a gun, and, most important, the overall homicide rate. ${ }^{189}$ Considerable care was taken in these studies to establish that the relationship was causal, although in the absence of experimental evidence there necessarily remains some doubt. The bulk of the evidence at this point suggests more prevalent handgun ownership engenders more widespread use of guns in crime and higher social costs of crime.

From a public health perspective, a concern for the effects of gun prevalence on suicide is as important as the effect on homicide. In fact, gun suicide is more common than gun homicide, although it seems fair to say that the threat of suicide does not have the same broad effects on quality of life as does the threat of violent crime. The assertion that gun availability influences the suicide rate may be questioned on the grounds that, unlike in the case of assault, someone who wishes to commit suicide has a choice of alternative mechanisms that can be equally as effective as a gunshot.

186. See Philip J. Cook, Jens Ludwig, S.A. Venkatesh \& Anthony A. Braga, Underground Gun Markets, 117 ECONOMICS J. 588 (2007).

187. See COOK \& LUDWIG, supra note 30, at 35-36.

188. See Azrael, Cook \& Miller, supra note _, at _; Gary Kleck, Measures of Gun Ownership Levels for Macrolevel Crime and Violence Research, 41 J. RES. IN CRIME \& DELINQUENCY 3 (2004).

189. See Cook \& Ludwig, supra note 10, at 387 (connecting the proxy for county-level gun prevalence to overall homicide rates); COOK \& LUDWIG, supra note 15, at _; Philip J. Cook \& Jens Ludwig, Does Gun Prevalence Affect Teen Gun Carrying After All?, $\overline{42}$ CRIMINOLOGY 27 (2004). 
Nonetheless, in the United States a majority of successful suicides are with guns, although guns are involved in only a small fraction of attempted suicides. Those determined to kill themselves can find a way but, for those attempting suicide on impulse, the lethality of readily available and psychologically acceptable weapons appears to matter. A recent review of the evidence by Matthew Miller and David Hemenway collects numerous case control studies comparing gun-owning households to observably similar households without guns, as well as ecological research pointing to the same conclusion. ${ }^{190}$ While this empirical research helps make the case, it is the logic and descriptive information on suicide that is most compelling to us.

If an ultimate consequence of Heller is increased handgun ownership in some jurisdictions, these likely effects on violent crime and suicide may be viewed as tangential to the intended effect of the decision-to safeguard the right of trustworthy householders to defend their home against intruders. In that light, perhaps the most relevant consequences of increased gun prevalence are the effect on residential burglary rates and home-invasion rates. Unfortunately we have no reliable data on the frequency with which householders actually do use a gun to defend against home invasion, or with what success. Certainly it happens occasionally, but how frequently remains a mystery. Survey data do not provide a reliable basis for finding the answer because self-reports in this instance are unreliable. Moreover, the estimated frequencies differ by an order of magnitude, perhaps depending on how the questions are asked. ${ }^{191}$

However, we can estimate the influence of gun prevalence on burglary rates and patterns. One study, which used a variety of data sets and methods, concluded that the prevalence of gun ownership in a county is positively related to the burglary rate. ${ }^{192}$ This association does not appear spurious, but rather most likely results from an inducement effect. Other things equal, residential burglary tends to be more profitable in communities where guns are likely to be part of the available loot. The rate of "hot" burglaries (break-ins of occupied homes) is also positively related to gun prevalence, although the effect is small.

190. See Matthew Miller et al., Household Firearm Ownership and Rates of Suicide Across the 50 United States, 62 J. Trauma 1029 (2007); Matthew Miller \& David Hemenway, Guns and Suicide in the United States, 359 N. ENG. J. MED. 989 (2008); M. Duggan, Guns and Suicide, in EVALUATING Gun POLICY, supra note _, at 41.

191. See Hemenway, supra note 42, at 69 (pointing to a large difference between assertions of some gun proponents and results from the National Crime Victimization Survey, which posed open questions to people who had actually reported an incident).

192. See Philip J. Cook \& Jens Ludwig, Guns and Burglary, in Evaluating GUN POLICY, supra note _, at 74. 
Let us review the chain of logic. To the extent that Heller and subsequent Court decisions make handguns cheaper and more readily available in some jurisdictions, those jurisdictions will likely experience an increase in demand for handguns and ultimately an increase in the prevalence of ownership. An increase in ownership prevalence will in turn make guns more readily available to criminals, thereby increasing gun use in violent crime and suicide, resulting in an increased death rate from intentional violence. Burglary rates are also likely to increase as burglary becomes more lucrative. But as it turns out, the first link of that chain-the connection between invalidating handgun bans and increased prevalence of handgun ownership - is the weakest empirically. It requires further discussion.

\section{b. Will Handgun Prevalence Increase in the District?}

The District of Columbia's ban on handgun acquisitions was enacted in 1976. But, by the late 1980s, the notion that the ban had achieved anything useful seemed unlikely, given common references to the city as the "Homicide Capital of the World."193 Of course we do not know how high the homicide rate spike would have been in the absence of the ban. Yet there is good evidence that the ban was ineffective in preventing members of the public from arming themselves during the turbulence of the 1980s.

In fact, homicides and suicides declined by approximately twenty-five percent around the time of the ban, led by reductions in homicides and suicides with guns ${ }^{194}$ _before the tsunami of violence stemming from the introduction of crack cocaine in the mid-1980s. Still controversial is the issue of how much of this decline can be attributed to the handgun ban rather than other factors.

In an influential article published in the New England Journal of Medicine, criminologist Colin Loftin and his colleagues showed that homicides and suicides declined in Washington, D.C., and by a greater margin than in the city's Maryland and Virginia suburbs. ${ }^{195}$ A challenge to the use of affluent suburbs as a control group for the city ${ }^{196}$ prompted

193. See Matthew Cella, Murder Rate Raises Concern, WASH. TimEs, Apr. 28, 2003, at B1. But cf. Vance Garnett, Op-Ed, Homicide: Will the Shake-Up Help?, WASH. POST, Sept. 28, 1997, at C8 (asserting that Newsweek coined the term with respect to D.C. in 1941).

194. See C. Loftin, D. McDowall, B. Wiersema \& T. Cottey, Effects of Restrictive Licensing of Handguns on Homicide and Suicide in the District of Columbia, 325 N. ENG. J. MED. 1615 (1991).

195. See id. at 1616-17.

196. See C.L. Britt, G. Kleck \& G. Bordua, A Reassessment of the D.C. Gun Law: Some Cautionary Notes on the Use of Interrupted Time Series Designs for Policy Impact Assessment, 30 L. \& SOC’Y REV. 361 (1996). 
additional research using Baltimore data. Like the District, Baltimore also experienced a decline in firearm homicides around 1976. But unlike the District, Baltimore experienced a reduction in both non-gun and gun homicides, suggesting some general change in Baltimore during this time period that was not specific to guns. Further, Baltimore did not experience a decline in gun suicides. ${ }^{197}$

It is interesting, then, to analyze gun-ownership rates in the District of Columbia and Baltimore during this period. Figure 1 tracks the proxy for gun ownership from the period before the ban until the end of the 1990s. The rate jumps up in the late 1980s, just as the crack epidemic was pushing up criminal violence-but Baltimore had quite a different trajectory during that time. Gun ownership has declined in the District since the early 1990s, and in recent years has dropped lower than when the ban was initiated in 1976 (and far lower than the national average). Perhaps the lesson from the early years is that a ban in a small jurisdiction with porous borders is difficult to enforce, especially in the face of broad concern caused by a major crime epidemic. Oddly, this may be good news for the District: It suggests that the removal of the handgun ban may have little effect, standing alone, on the prevalence of handgun ownership.

The data hint at a similar pattern in Chicago, home to the other notable handgun ban susceptible to legal challenge following Heller. In 1982, Chicago essentially banned private ownership of handguns, with a grandfather exception enabling those already in possession of handguns to register them with the city. Figure 2 shows that FSS in all of Cook County declined somewhat during a brief period after the city's ban was enacted, but then reverted to pre-ban levels. ${ }^{198}$ Whether the FSS in Chicago proper followed the same pattern is unknown; the city has only about half of the County's suicides. ${ }^{199}$

In sum, the effect of these local handgun bans on the prevalence of gun ownership is uncertain, although there is some indication that it has not been large. This does not mean that these and other interventions have no effect on the prices and availability of guns. Fortunately, the underground gun market in Chicago does not work well, and young people and criminals tend to have a difficult time obtaining a gun if they are not gang members. ${ }^{200}$ The handgun ban and the ban on licensed dealers in that city may contribute

197. See D. McDowall, C. Loftin \& B. Wiersema, Using Quasi-Experiments to Evaluate Firearms Laws: Comment on Britt et al's Reassessment of the D.C. Gun Law, 30 L. \& SOC'Y REV. 381 (1996).

198. See also Philip J. Cook \& Jens Ludwig, The Effects of the Brady Act on Gun Violence, in GUNS, CRIME, AND PUNISHMENT IN AMERICA 283 (Bernard E. Harcourt ed., 2003).

199. See Illinois DeP'T OF PUBlic HeAlth, Vital Statistics: COUNTy Vital STATISTICS 95, 123 (2002), available at http://www.idph.state.il.us/health/statshome.htm.

200. See Cook et al., supra note 186. 
to these frictions. But available data leads us to question whether judicial invalidation of (weakly enforced) handgun bans would seriously threaten social welfare. The general political hostility to such prohibitions adds to our skepticism. It is therefore plausible that the most obvious implication of Heller for formal law has little significance for sound and politically feasible gun control.

Figure 1: PERCENT Suicides With Guns in WASHington, DC, AND

BALTIMORE, MARYLAND ${ }^{201}$

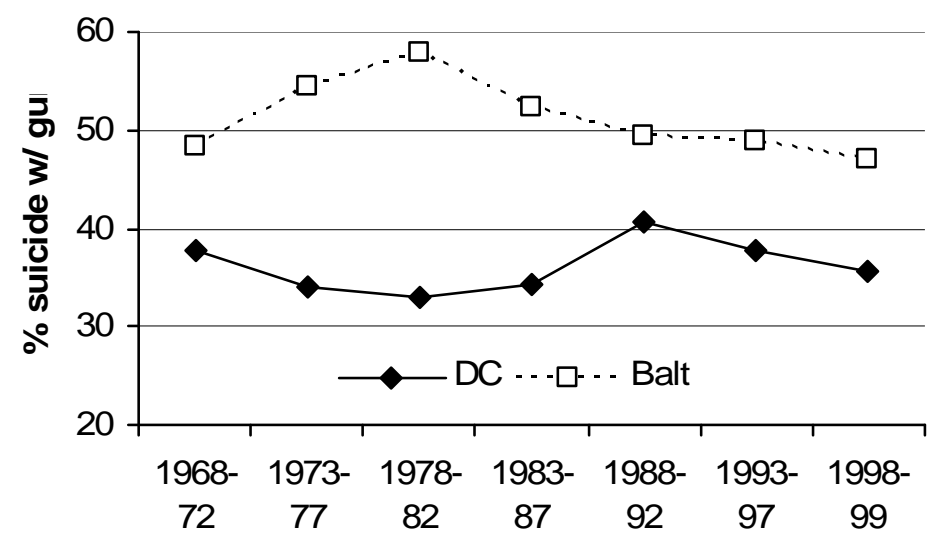

Figure 2: PERCENT SuICIDES WITH GUNS IN COOK COUNTY AND THE REST OF ILLINOIS ${ }^{202}$

201. Figure 1 presents five-year averages for the percent of suicides committed with guns, a proxy for household gun ownership rates. See supra notes 188-189.

202. Figure 2 presents five-year averages for the percent of suicides committed with guns, a proxy for household gun ownership rates. See supra notes 188-189. 


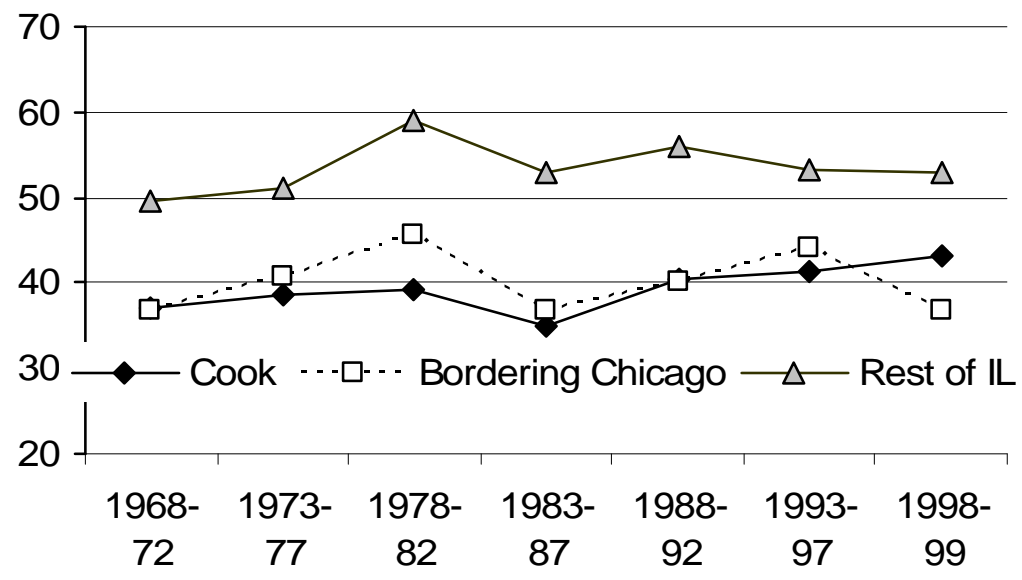

C. Public Places and Concealed Carry

In addition to the issues of incorporation and municipal handgun bans, Second Amendment litigation will likely address a right to carry weapons in public places. Whether otherwise qualified gun owners should be entitled to carry firearms beyond their homes and into generally accessible locations, including a right to carry concealed firearms, has been on the policy agenda for more than a century. The Supreme Court itself, in dicta from 1897, indicated that the Second Amendment does not protect concealed carry. ${ }^{203}$

But this suggestion might be reconsidered or left narrow by reliance on Heller's self-defense theme. It could be argued that protecting oneself from violence in high-crime areas is no more important within the home than out in the open. True, this argument runs into some of Heller's hedging on handgun rights. During its discussion of limits on Second Amendment rights, the majority opinion observed that nineteenth-century state court cases had usually rejected constitutional claims to a right of concealed carry. ${ }^{204}$ Elsewhere, however, the majority noted some nineteenth-century judicial support for a right to unconcealed pistols. ${ }^{205}$ Part of that

203. See Robertson v. Baldwin, 165 U.S. 275, 281-82 (1897) ("Thus, the freedom of speech and of the press (article 1) does not permit the publication of libels, blasphemous or indecent articles, or other publications injurious to public morals or private reputation; the right of the people to keep and bear arms (article 2) is not infringed by laws prohibiting the carrying of concealed weapons ....”.).

204. See Heller v. District of Columbia, 128 S.Ct. 2783, 2816 (2008).

205. See id. at 2809, 2818. 
jurisprudence is, to put it politely, unrelated to modern forms of public policy analysis, but it does suggest that gun rights can extend into public places without including concealed carry. Thus an 1850 decision from Louisiana lauded "a manly and noble defence" with unconcealed weapons while disparaging "secret advantages and unmanly assassinations" with concealed weapons. ${ }^{206}$

However the courtroom arguments about gun rights in public (or manliness) might play out in the twenty-first century, our question is whether one result would have significantly different consequences from another. It is certainly true that permit systems of some kind are a politically viable form of gun control in many jurisdictions. Indeed, almost all states require that legal gun owners obtain a permit to carry a concealed firearm in public, although over time a growing number of states have relaxed their requirements for issuing such permits. ${ }^{207}$ What would it mean to social welfare if otherwise qualified citizens possessed a federal constitutional right to carry guns in public, whether openly in a holster or concealed on their person? What if this right were subject to approval through a permit system? There is no uncontroversial answer to these questions, especially in light of the different forms that a right to public carry might take. But we can present salient arguments and existing empirical data. ${ }^{208}$

Those who wish to encourage gun carrying in public places by private parties argue that the increased likelihood of encountering an armed victim will deter criminals. This possibility receives some support from prisoner surveys: eighty percent of prisoners in one survey agreed with the statement that "a smart criminal always tries to find out if his potential victim is armed." ${ }^{209}$ But the same data also raise the possibility that an increase in gun carrying could prompt an arms race. Two-thirds of prisoners

206. State v. Chandler, 5 La. Ann. 489, 490 (1850).

207. See John A. Dvorak, Concealed Weapons Laws Taking Hold, Broadening Across U.S., KNIGHT-RIDDER/TRIB. NEWS SERV., Mar. 1, 2002, available at http://www.highbeam.com/doc/1G1-83407220.html.

208. It is possible that law enforcement officers' stop-and-frisk authority would be curtailed if the courts established a right to carry concealed weapons in public. Police officers might have more difficulty establishing reasonable suspicion of criminal activity to support a stop, see Terry v. Ohio, 392 U.S. 1, 30-31 (1968), although stops might often be justified on grounds not necessarily related to illegal gun possessioin, such as suspicion of drug crimes. But, in any event, the officer safety justification for the stop-and-frisk doctrine seems adequate to preserve pat downs and weapons seizures during certain police-citizen encounters regardless of whether police suspect unlawful or lawful gun possession. See id. at 23-24, 29-30. A hitch for police officers might be their authority to keep seized weapons at the end of a street encounter if the citizen is not arrested, lawfully possesses the firearm, and asks for the weapon back on the spot. These interchanges might be risky yet implicate a broad view of Second Amendment rights.

209. See WRIGHT \& RossI, supra note 26, at 145. 
incarcerated for gun offenses reported that the chance of running into an armed victim was very or somewhat important in their own choice to use a gun. ${ }^{210}$ Currently, criminals use guns in only about twenty-five percent of noncommercial robberies and five percent of assaults. ${ }^{211}$ If increased gun carrying among potential victims causes criminals to carry guns more often themselves, or become quicker to use guns to avert armed self-defense, the end result could be that street crime becomes more lethal. ${ }^{212}$

In a provocative series of research papers and books, economist John Lott has argued that the deterrent effects of moving from restrictive to permissive gun-carrying laws dominate. ${ }^{213}$ On the other side economist John Donohue argues that, while Lott's analysis improves on previous research on this topic, Lott's findings cannot support the conclusion that ending restrictive concealed-carry laws reduces crime. ${ }^{214}$ Donohue's reanalysis of the Lott data indicates that states that eventually ended restrictive concealed-carry laws had systematically different crime trends from the other states even before these law changes went into effect. The tendency to adopt the law under study following an unusual spike in crime-which would ordinarily be followed by a reduction regardless of whether a new law were passed-makes the analysis problematic. Indeed, Donohue finds much evidence in support of the view that these laws increased crime rates in the 1990s, when crime was generally declining. Hence the estimated treatment effect may in fact be due to whatever unmeasured factors caused crime trends to diverge before the laws were enacted.

Regardless of who gets the better of this particular debate, we want to stress the issue of magnitudes. Whether the net effect of relaxing concealedcarry laws is to increase or reduce the burden of crime, there is good reason to believe that the net is not large. One study found that in twelve of the sixteen permissive concealed-carry states studied, fewer than two percent of

210. See id. at 147.

211. See Michael R. RAND, Criminal Victimization 2007, at 6 (Bureau of Justice Statistics, Dec. 2008) (reporting, as well, that offenders used firearms in $7.1 \%$ of all violent crimes in 2007).

212. The analysis is complicated by the choice between rights to carry concealed as opposed to unconcealed weapons outside the home. If people have a right to carry handguns in public but the government could validly and effectively mandate unconcealed carry, then potential aggressors would receive reliable information regarding which would-be victims are most vulnerable. Perhaps unconcealed carry cannot be effectively required. But such a regime of rights and regulations (that is, mandatory unconcealed carry) could be meaningfully different from a legal regime in which people have a right to choose whether or not to conceal their weapons (that is, optional concealed carry) - or in which government mandates concealment for any person otherwise entitled to possess a weapon in public (that is, mandatory concealed carry).

213. See LOTT, supra note 74, at 115; John R. Lott \& D.B. Mustard, Crime, Deterrence and Right-To-Carry Concealed Handguns, 16 J.L. STUDIES 1 (1997).

214. See John J. Donohue, The Impact of Concealed-Carry Laws, in EvaluATING GuN POLICY, supra note _, at 287. 
adults had obtained permits to carry concealed handguns. ${ }^{215}$ And the actual change in gun-carrying prevalence will be smaller than the number of permits issued would suggest, because many of those who obtain permits were already carrying guns in public. ${ }^{216}$ Moreover, the change in gun carrying appears to be concentrated in rural and suburban areas where crime rates are already relatively low, among people who are at relatively low risk of victimization - white, middle-aged, middle-class males. ${ }^{217}$ The available data about permit holders also imply that they are at fairly low risk of misusing guns, consistent with the relatively low arrest rates observed to date for permit holders. ${ }^{218}$

Based on available empirical data, therefore, we expect relatively little public safety impact if courts invalidate laws that prohibit gun carrying outside the home, assuming that some sort of permit system for public carry is allowed to stand. The result would most likely be a modest change in gun carrying rates among a subset of the population that is itself at relatively low risk of either gun offending or victimization. Of course, we cannot confidently predict that a judicially enforceable right to public carry would not change the composition of those who carry guns in public; and the effects on public safety could be different depending on whether any such right includes the choice to conceal as opposed to openly carry a firearm outside the home. As well, our analysis would be different if a right to public carry were coupled with an enlargement of the class of people entitled to acquire firearms beyond what today's permitting systems already allow, or if government were not allowed to operate a permit system at all. Even if the test for issuance is fairly permissive, imposing a permit requirement might well affect the composition of gun carriers in positive ways. On the available data, however, the issue of public carry standing alone seems more likely to be litigated than to seriously affect social welfare.

\section{Gun-Targeted Taxes, Safety Programs, and Policing}

Given the discussion above and the Heller majority's apparent commitment to immunizing much of the existing gun control regime, the

215. See J.M. Hill, The Impact of Liberalized Concealed Weapon Statutes on Rates of Violent Crime _ (1997) (unpublished senior thesis, Duke University, Public Policy).

216. See G. Robuck-Mangum, Concealed Weapon Permit Holders in North Carolina: A Descriptive Study of Handgun-Carrying Behavior University of North Carolina, School of Public Health).

217. See Hill, supra note 215, at _.

218. See LOTT, supra note 74, at 37-39, 185 n.1, 197 n. 22. 
stakes of Second Amendment litigation seem low. But there might be greater threats to sound public policy in the future.

Our first concern is that courts might someday hold that special regulatory treatment of firearms is prima facie evidence of a constitutional violation. That is, judges might consider it presumptively problematic that government action singles out firearms or handguns, and then require a justification so demanding that reasonably reliable evidence and logic become insufficient for gun control to survive. Demanding anything like mathematical certainty that a regulation will enhance public safety at acceptable cost would jeopardize large swaths of existing and potential gun control efforts. Everything from gun taxes, to gun design requirements, to gun safety programs involving permits and licenses, to gun registration and information collection efforts, to gun-oriented policing in high-violence neighborhoods could be disrupted-unless regulators show analogous treatment of other products or otherwise survive skeptical judicial scrutiny of the program's value.

Nothing in Heller commits the Court to this path, but it would not be entirely foreign to constitutional adjudication. Free speech and free exercise of religion doctrine includes this sort of anti-targeting structure. ${ }^{219}$ In these fields the modern Court has often concentrated on government action that not only burdens behavior the justices believe constitutionally valued, but that singles out such behavior for special disfavor. To be clear, this antitargeting approach does not fit all of the doctrine. ${ }^{220}$ Nor is it easy to identify which forms of regulatory targeting ought to be problematic. This requires a theory. For instance, the Court has been relatively unconcerned when government regulates the time, place, or manner of speech without explicitly targeting speech content, ${ }^{221}$ even though such choices can be crucial to speakers and audiences. Regardless, one must have a justifiable definition of "the freedom of speech" before one can tell whether regulation targets the phenomenon. It is not at all obvious how "the right to keep and bear arms" should be fully specified, and then how the doctrinal categories from free speech or free exercise litigation might be imported into the gun rights field. It is nevertheless worth raising the First Amendment analogy. The Heller majority did so in several places. ${ }^{22}$

219. See generally Adam M. Samaha, Litigant Sensitivity in First Amendment Law, 98 Nw. U. L. REV. 1291, 1294 (2004).

220. See id. at 1318, 1355-71 (identifying situations where claimant conduct matters to formal First Amendment doctrine and its functions).

221. See, e.g., Ward v. Rock Against Racism, 491 U.S. 781, 791 (1989).

222. See District of Columbia v. Heller, 128 S.Ct. 2783, 2790-91, 2797, 2799, 2805, 2812, 2813 n. 23, 2816, 2817 n. 27, 2821 (2008) (connecting First and Second Amendment text, history, and judicial treatment). 
Consider in this regard a tributary of speech doctrine that leans hard against special taxation of the traditional press. In 1983, the Court declared invalid a state tax on paper and ink used for producing publications, with exemptions for the first $\$ 100,000$ worth-even though it appeared that the complaining newspapers would have paid more under the state's general sales tax. ${ }^{223}$ On the other hand, the Court has repeatedly rejected press claims for exemption from regulation that reaches other industries, despite the real economic burdens that may be imposed on the media: The Court grants media operations no constitutional immunity from labor or antitrust laws that are applicable to other businesses. ${ }^{224}$ This kind of logic might be exported to Second Amendment litigation. Indeed, regulatory cost concerns have already arisen after Heller. Plaintiffs challenging gun control in Chicago are not only objecting to the city's handgun ban, they also seek invalidation of a recurring firearms registration and fee requirement. ${ }^{225}$

Now consider the federal excise tax. Since 1919, the federal government has collected an excise tax on firearms. ${ }^{226}$ This one-time tax on sales now stands at ten percent of the manufacturer's price for handguns and eleven percent for long guns. ${ }^{227}$ At least part of this tax is surely passed along to consumers. Even if a tax burden by itself will not trigger heightened judicial skepticism, a post-Heller judiciary might nevertheless ask whether a firearms tax law is special compared to other taxation schemes and whether the government can explain the differences persuasively. If firearms are taxed like sporting goods, perhaps judges become passive; but if they are taxed in a unique way, perhaps judges become inquisitive. It is of course possible for government lawyers to defend special treatment for firearms by linking their prevalence or misuse to social harm and to the level of taxation or other regulation in question. But case outcomes would depend upon what kind of logic is persuasive to judges and how much evidence they demand to support the regulation. And of course taxation can be the product of political opportunity and demand elasticities rather than distinctions that a judge will deem principled.

223. See Minneapolis Star \& Tribune Co. v. Minnesota Comm'r of Revenue, 460 U.S. 575, 577-79, 588-91 (1983) (expressing concern that judges will not be able to calculate tax burdens); id. at 597-98 (Rehnquist, J., dissenting) (comparing liability under the sales tax). The sales tax was not necessarily the correct baseline from which to compare; exemptions to the paper-and-ink tax meant that only a few large newspapers paid the tax.

224. See Cohen v. Cowles Media Co., 501 U.S. 663, 669-70 (1991); Associated Press v. NLRB, 301 U.S. 103, 132-33 (1937).

225. See supra note 133 .

226. See Revenue Act of 1918, Pub. L. No. 254, ch. 18, tit. IX, sec. 900(10), 40 Stat. 1058 (Feb. 24, 1919).

227. See Alcohol \& Tobacco Tax \& Trade Bureau, Tax and Fee Rate, available at http://www.ttb.gov/tax_audit/atftaxes.shtml. Ordinary wine is taxed at only 21థ/bottle. 
If courts are sufficiently demanding and if they are sufficiently sensitive to cost increases from firearms regulation, there could be major losses in social welfare. Minimizing the cost of acquiring firearms obviously benefits those who sell and those who enjoy possessing them, but these gains arrive with threats. One worrisome possibility is that concerned judges would invalidate gun control efforts or targeted taxation with a reasonable chance of seriously improving public health and safety but that is nevertheless experimental. Furthermore, gun-targeted laws can be designed to offset negative externalities that empirical study is associating with firearms. By one estimate, keeping a handgun in the home is associated with at least $\$ 600$ per year in externalities. ${ }^{228}$ On the usual logic of corrective taxation, it would pay to raise the current firearms tax rate so that handgun owners internalize the full social costs of their choices. ${ }^{229}$ Attempts to tax or otherwise regulate firearms based on estimates of their social costs are threatened by constitutional doctrine that flatly disfavors such special treatment absent conclusive proof of those social costs. Even information collection systems could be at risk. ${ }^{230}$

228. See Cook \& Ludwig, supra note 10, at 390.

229. Apart from taxation, liability insurance is an alternative mechanism for the internalization of externalities associated with gun ownership. A standard homeowners' insurance policy ordinarily covers liability for accidents involving guns, but often with an exemption for intentional harms, or even for harms resulting from criminal acts. See Tom Baker \& Thomas O. Farrish, Liability Insurance and the Regulation of Firearms, in SUING THE GUN INDUSTRY 292 (T. Lytton ed., 2005); Tom Baker, Liability Insurance at the Tort-Crime Boundary, in FAULT LinES: Tort LAW And Cultural Practice (D.M. Engle \& M. McCann eds., forthcoming 2009) (manuscript at 7), available at http://papers.ssrn.com/sol3/papers.cfm?abstract_id=1314309. It is not clear how far liability or liability coverage extends for cases in which the gun is transferred by the owner to someone else, or stolen, and then misused. To the best of our knowledge, no states or localities require gun owners to obtain such insurance. The threat of litigation following Heller could stifle local experiments with such policies.

230. The public safety consequence of repealing licensing and registration systems is a bit unclear based on available evidence. These systems do provide information regarding who owns what guns, information that could prove useful to law-enforcement investigations. The most vivid example is in the future. The California law requiring pistols sold after 2010 to have micro-stamp capability will be more useful if the state is allowed to continue handgun registration; the regulatory combination should help investigators connect shell casings found at the scene of a crime and the current or recent owner of the gun. Unfortunately, evaluation of existing state-level licensing and registration systems is forced to rely on weak research designs, yielding evidence for regulatory impact on immediate output measures but not on outcomes of more direct policy interest. For example, D.W. Webster, J.S. Vernick \& L.M. Hepburn, Relationship Between Licensing, Registration and Other Gun Sales Laws and the Source State of Crime Guns, 7 INJURY PREVENTION 184 (2001), finds some effect of licensing and registration requirements on the fraction of confiscated crime guns that were first purchased out of state. How informative this is about the ease with which criminals can obtain guns, or ultimately the overall rate of gun crime within a community, is unclear. A study of the federal Brady Act suggests the ability of the secondary gun market to shift and at least partially offset changes to the supply side of the market. After Brady was enacted, Chicago experienced a large drop in the share of crime guns first sold out 
To economists, the effect of taxation and other requirements on the price of guns is not just an incidental detail, but rather may have an important effect on gun sales, use, and misuse. It seems apparent that the most important health-related outcome likely to come from the cigarette litigation has been the increase in the price of cigarettes resulting from the financial settlement with the states. ${ }^{231}$ The tax on new guns, though much more modest proportionally, should also have some effect on demand, reducing the number of guns and the prevalence of gun ownership by some amount. The economic logic here rests on the strong presumption that a tax on new guns will be passed on to the secondary market by restricting the quantity available from the primary market. ${ }^{232}$ The same price effect can be achieved by imposing permit fees or by establishing minimum quality standards - as with the ban on imports of low-quality handguns-or by requiring special features on new guns, such as locking devices or microstamp capability. But these initiatives tend to make guns special from a regulatory perspective.

We have reason to believe, however, that courts will not aggressively follow an anti-targeting theme in Second Amendment doctrine. First, for reasons noted above, judges are unlikely to radically uproot gun control regardless of the doctrinal forms they adopt. Second, an anti-targeting theme is not necessarily sensible for the Second Amendment as a matter of lawyers' logic. It depends on what motivates courts to single out singling out, so to speak.

Part of the motivation derives from a conclusion that an enormous variety of government action can negatively influence the exercise of constitutionally valued behavior, and that not every adverse effect can or should be policed by courts. ${ }^{233}$ This limit on judicial ambition does seem equally applicable to Second Amendment litigation. If mass media must pay property taxes, and if the Constitution is no barrier to enforcing religiously-neutral drug laws against religious ritual, ${ }^{234}$ then it is difficult to see why handguns cannot validly be subject to a general sales tax or to premarket approval from a product safety commission, for example.

of state, yet the fraction of homocides committed with a gun did not seem to change at all. See Cook \& Braga, supra note 26, at 304-07; Cook \& Ludwig, supra note 190, at 21-22.

231. See Frank J. Chaloupka \& Kenneth E. Warner, The Economics of Smoking, in 1B HANDBOOK OF HEATH ECONOMICS 1539, 1546-56 (Anthony J. Culyer \& Joseph P. Newhouse eds. 2000) (reviewing studies for the proposition that monetary price increases tend to reduce cigarette demand, despite the product's addictive qualities).

232. See Philip J. Cook \& J.A. Leitzel, Perversity, Futility, Jeopardy: An Economic Analysis of the Attack on Gun Control, 59 L. \& CONTEMP. PROBS. 91 (1996).

233. See, e.g., Larry Alexander, Trouble on Track Two: Incidental Regulations of Speech and Free Speech Theory, 44 HASTINGS L.J. 921 (1993).

234. See Employment Div. v. Smith, 494 U.S. 872 (1990). 
The complication arises from the necessity of identifying which forms of regulatory targeting might be constitutionally troubling. It is not enough for a court to recognize constitutional value in the private conduct at issue. Such value is jeopardized whether or not regulators single it out for special treatment. To enforce an anti-targeting theme while minimizing or ignoring other government-instigated burdens, judges ought to have a convincing reason for their skepticism of regulatory targeting itself.

In the free speech field, one might conclude that government regulation isolating particular messages for uniquely burdensome treatment is presumptively problematic. This could be based on a theory that, say, government officials are especially likely to use such regulation to entrench their own power and to freeze the political environment against logical testing and innovation. ${ }^{235}$ And we might believe that, in general, forcing the political system to treat communication more like other conduct provides a handy safeguard. Speakers will thereby have natural allies in the democratic process who are likewise threatened with regulatory burden. ${ }^{236}$

But we have doubts that courts could faithfully translate this logic into the gun rights domain. We are aware of no convincing theory of just political power that identifies the gun rights movement as in need of federal judicial assistance. This movement is anything but a perennial loser in ordinary politics, and a judicial attempt to multiply allies for the gun lobby would be hard to justify on a reasonable vision of equitably distributed political influence. One might believe that existing gun control is too onerous without believing that the political process is rigged in its favor.

Nor is it clear what special skepticism the judiciary should have when it comes to firearms regulation. If we focus on Heller's reasoning, the majority's key concern was handgun possession for self-defense in the home. It is doubtful that regulators surreptitiously harbor ill will toward those hoping to protect themselves against criminal intruders, or that they will often use firearms regulations as a method for squelching self-defense efforts. Had Heller emphasized the problem of centralized tyranny, our analysis would be different. But it did not. The majority's vision for the right was mainstreamed and demilitarized. ${ }^{237}$ Once the rationale for gun rights moves away from tyranny of the central government and towards more mainstream values such as self-defense from private criminal assault,

235. See, e.g., FredericK SCHAUER, FreE SPEECH: A PHILOSOPHICAL ENQUIRY 43-44, 80 86 (1982) (suggesting regulation might be distrusted more than speech is especially valued).

236. See, e.g., KATHLEEN M. SUlLivan \& GERALD GunTHER, FIRST AMENDMENT LAW 205 (3d ed. 2007). There are other theories that might support anti-targeting themes and yet still weaken the case for substantial burdens tests; perhaps a targeted burden amounts to a special form of injury. But this is a start.

237. See supra Part II.A. 
judges would seem to have less reason to worry that specialized gun regulation is one step toward a constitutionally prohibited end.

This is not to claim that courts have no basis on which to invalidate firearms regulation beyond comprehensive handgun bans. Our point is that the path toward an anti-targeting theme in Second Amendment doctrine is logically challenging. And a substantial burden analysis would yield a pattern of outcomes that it is not easy to predict. Our concern remains that, however controversial the legal logic, courts will borrow an anti-targeting theme from elsewhere in constitutional doctrine and then subject nearly all gun control efforts to substantial judicial review. While we hold to our sense that courts will not radically revise firearms law in the United States, confirming that prediction of judicial modesty might happen only after much litigation — and with an additional cost in the form of regulatory stasis.

\section{E. Judicial Review and Innovation}

This brings us to a more diffuse yet equally troublesome risk of Second Amendment litigation. The Supreme Court's willingness to inject the judiciary into the gun control arena could have a socially detrimental dampening effect on regulatory innovation. This should be of concern to anyone who believes that gun policy in America has come to an unfortunate stalemate, and that the future might open political opportunities for novel regulatory approaches that overcome current ideological cleavages and do more good than harm.

Granted, constitutional law does not necessarily kill innovation. The relationships among constitutionalism, judicial review, and regulatory innovation are actually quite complex. One description of constitutional law in the United States has emphasized entrenchment of old norms against change, but many observers now recognize that a constitutional order can generate institutions to make change. ${ }^{238}$ Judicial review is no different. It might retard or instigate regulatory innovation, depending on how it is performed. For example, nonjudicial policymakers might respond to judicial invalidations with new regulatory approaches in an effort to respect both judicial judgments and public demands. Roe v. Wade did not end the

238. See, e.g., STEPHEN Holmes, PAssions AND CONSTRAint: ON THE THEORY OF LiBERAL DEMOCRACY 153 (1995) ("The American Constitution is an instrument of government, not an obstacle to government...."); Adam M. Samaha, Dead Hand Arguments and Constitutional Interpretation, 108 COLUM. L. REV. 606, 631, 662-63 (2008) (discussing coordination theories of authority for our constitutional text). A provocative argument for valuing constitutional debate precisely for its ability to combat entrenchment is LOUIS MICHAEL SEIDMAN, OuR UnSETTled CONSTITUTION: A NEW DEFENSE OF CONSTITUTIONALISM AND JUDiCiAL REVIEW 55, 210-16 (2001). In this regard, consider that Heller itself effectively disrupted a status quo in judicial review against Second Amendment claims. 
development of abortion law and Heller did not end the District of Colombia's gun control efforts. ${ }^{239}$ In addition, the very substance of constitutional doctrine can mandate periodic updating in ordinary law. An illustration is Eighth Amendment doctrine's focus on evolving standards of decency. ${ }^{240}$ We can imagine a Second Amendment doctrine that likewise calls for evaluation of gun control according to contemporary values and circumstances.

But the possibility of constitutional litigation certainly can deter novel government responses to old or new social problems-and passages in Heller seem crafted to have this dampening effect. Recall the majority's reliance on eighteenth- and nineteenth-century sources for guidance on the Second Amendment's meaning, its reference to a tradition of prohibiting dangerous or unusual weapons, and its apparent preference for longstanding gun control measures. ${ }^{241}$ Even if these forays into originalist history and subsequent tradition leave readers uncertain about what counts as unacceptable novelty in gun control, and even if some type of interest balancing was operating in the background, the Court's official rationale looks largely unsympathetic to policy experimentation. At this point, moreover, we cannot be certain that fighting comprehensive handgun bans will exhaust judicial opposition to firearms regulation. There is now a substantial range of plausible litigation threats while the Court's position on gun control remains vague. These threats can prevent policy experiments before they begin.

It might be fair to ask whether the demand for innovative responses to gun risks is appreciable in the current political environment. One might believe that the policy rut is too deep for Second Amendment litigation threats to make much difference. But we believe that policy innovation is alive in some states and localities. Jurisdictions including California, Maryland, and Massachusetts have moved forward with new gun control policies in recent years. ${ }^{242}$ Relatively innovative ideas include microstamping shell casings for the purpose of tracing crime guns, reviewing the design of new guns before they hit the market, and personalized gun technology that attempts to restrict usage to owners only. Perhaps less mainstream but nevertheless intriguing is the possibility of taxing firearms according to their estimated social costs, or requiring firearms owners to maintain insurance to cover the costs of gun misuse by themselves or others. Some such innovation might be analogized to existing regulation of other commodities, but these ideas would be new with respect

\footnotetext{
239. See supra note 113.

240. See, e.g., Kennedy v. Louisiana, 128 S.Ct. 2641, 2664-65 (2008).

241. See supra text accompanying notes 139-147.

242. See supra Part I.C.1-I.C.4.
} 
to firearms. A tradition-oriented Second Amendment doctrine would undercut them.

Furthermore, the political environment for firearms regulation can change. Opportunities for new policy rise and fall with such factors as changing demographics and the salience of gun violence; if the decline in sporting uses of guns continues to sap NRA membership efforts, if violent crime spikes upward again, and if we witness another Virginia Tech-style massacre, the politics will tend to change. But a tradition-enforcing form of judicial review can minimize these regulatory opportunities. In fact, this politically countercyclical role for judicial oversight helps explain the oddity of 305 members of Congress supporting constitutional litigation against the District of Columbia, rather than simply voting to override the District's regulations. ${ }^{243}$ Heller could help freeze some existing political victories on the gun rights side, victories that kept gun control mild and that make Heller look unimportant at the moment.

Heller might put a brake on new gun control policy through two mechanisms. First, at least some proposals will be debated under a serious threat of constitutional litigation with its attendant costs for the government. These costs are not limited to financing an adequate legal defense; losing a Second Amendment challenge might mean paying damages or attorneys fees to the claimants. And litigation threats against innovative regulation will remain strong unless and until Second Amendment doctrine is clarified in relevant respects. Consider California's cutting edge rule that, beginning in 2010, semiautomatic pistols must be designed to stamp a serial number on the shell casing each time a round is fired. ${ }^{244}$ Whether this requirement will pass constitutional muster is not fully known at the moment, and the issue may not be settled for many years. Meanwhile, legislators in other states who are attracted to this idea as a boon to police investigations will have to persuade the majority that it not only serves the public interest, but that it is worth the expected cost of defending it in the courts. Even if microstamping is somehow insulated from serious Second Amendment objections, in some cases the expected litigation costs will be prohibitive.

The second mechanism is more speculative but it might be significant. Heller transformed the notion of personalized Second Amendment rights from contested to justiciable. The decision could therefore strengthen the rhetorical arsenal of gun rights supporters, even if these advocates have

243. See supra note 4. It is possible that the Senate's commitment to supermajority votes for cloture against filibusters led this simple majority of Congress members to prefer constitutional litigation to ordinary legislation. If so, the shift to litigation is a consequence of the legislators' own institutional design choices. On constitutional objections to the filibuster itself, see Adam M. Samaha, Undue Process, 59 STAN. L. REV. 601, 608-09, 667-68 (2006).

244. See supra note 83. 
gone beyond Heller's language. ${ }^{245}$ It is hard to predict the political effect that this shift will have in practice, but it may be nontrivial. The hopeful view of gun control advocates, that Heller would open the door to moderate legislation by undercutting the rhetorical force of the slippery slope argument, ${ }^{246}$ is yet to be confirmed and might be naïve.247 On the other hand, the case could ultimately have no meaningful effect on constitutional argument outside the courts. Second Amendment objections to gun control predate Heller by decades, and the movement behind those arguments helps explain the decision rather than the other way around. In addition, Heller demilitarized the amendment in a way that preserves key elements of modern gun control. Thus if judicial rhetoric influences nonjudicial debate, the influence might cut in two directions.

Even if Heller deters the implementation of some number of firearms policies that are worth trying, there is nevertheless a modest hope for improved policy quality in the regulation that does go forward. The Supreme Court intervened late in the development of gun regulation in the United States, and some might view the current system as dysfunctional. The less respect one has for gun politics today, the more one might hope that a dose of judicial oversight will prove net beneficial. The comparison is not between uninformed judges redrafting firearms law and an ideal world of policymaking in which people's values are fairly ascertained while experts collect relevant data which is then used to construct social welfare maximizing regulation. In the United States, authority over firearms regulation is often maintained within state legislatures responsive to the distribution of organized political power, not in localities sensitive to local conditions or administrative agencies building expertise on the potential and limits of gun control. And if Second Amendment doctrine beyond the core right recognized in Heller calls for sober consideration of rational argument and empirical data, our current system of gun politics and regulation might make progress toward sound policy.

But this hope is no more than modest. The first problem is that we cannot guarantee that any improvement in policy quality will outweigh the value of foregone policy experiments. It almost goes without saying that we

245. See National Rifle Ass'n, Supreme Court Declares that the Second Amendment Guarantees an Individual Right to Keep and Bear Arms (June 26, 2008) ("All law-abiding Americans have a fundamental, God-given right to defend themselves in their homes. Washington, D.C. must now respect that right.”), available at http://www.nraila.org/heller/.

246. See David M. Kennedy, Now Reason Can Prevail, NAT'L L.J., vol. 31, no. 4, at 27 (Sept. 22, 2008).

247. Cf. Nat'l Ass'n for Gun Rights, The Truth About the Heller Decision (July 29, 2008) (exhorting supporters to fuel pro-gun lobbying efforts because "liberals are using [Heller] to restrict our gun rights,” and criticizing the decision for recognizing longstanding prohibitions on certain types of gun use), available at http://www.nationalgunrights.org/truthaboutheller.shtml. 
have more to learn about the characteristics of effective gun control that adequately accounts for the benefits of gun ownership. Second, judges are, at best, only marginally better at understanding the complexities of gun policy analysis than others involved in the system. They are not experts and they are unlikely to acquire the relevant expertise in short order, even if they act in good faith. Whether judges are able to incorporate values held by the general public rather than implement their own personal policy preferences is another serious question, if the goal is social welfare maximization.

Finally, the post-Heller litigation environment is decidedly asymmetrical. Gun rights proponents now have an additional method for achieving their goals, while gun control proponents will ordinarily lack conventional constitutional arguments to prompt gun regulation. PNonjudicial politics ultimately preempted many lawsuits against the gun industry, and now the Supreme Court has made it possible for the gun rights movement to press further in the other direction with supreme judicial review. To the extent that Second Amendment litigation prompts deeper and empirically driven evaluation of firearms regulation, it will come with gun control in a systematically defensive posture. We have little confidence that this one-sided drag on policy innovation can produce sufficient gains to provide a net benefit.

For some, an additional veto gate for gun control in the courtroom will be a welcome change. But a libertarian presumption against government action is not self-evidently good policy from a social welfare perspective. And so we remain concerned that the greatest risk to sound public policy following Heller is among the least visible: an additional background pressure against novelty in the law of gun control at a time in which experimentation and creative decisionmaking is crucial.

\section{CONCLUSION}

Heller begins a new era in the history of gun control. It adds federal constitutional adjudication to the policymaking environment in a novel way, without determining much of the future for Second Amendment doctrine. We have attempted to understand the dimensions and underpinnings of the decision, and to evaluate its plausible consequences for social welfare. That perspective and the available data lead us to believe that some obvious constitutional issues, such as the validity of nonfederal handgun bans and of concealed carry laws, are not especially threatening. Yet other possible outcomes, such as judicial skepticism of gun-targeted regulation that increases firearms prices and litigation risks that chill regulatory innovation, ought to be matters of serious concern. Our analysis is itself only a beginning. But one important task after Heller is to separate true threats 
from sideshows in the continuing struggle to reduce crime and violence in America. 
Readers with comments should address them to:

Professor Adam M. Samaha

University of Chicago Law School

1111 East 60th Street

Chicago, IL 60637

asamaha@uclaw.uchicago.edu 


\section{Chicago Working Papers in Law and Economics (Second Series)}

For a listing of papers 1-399 please go to Working Papers at http://www.law.uchicago.edu/Lawecon/index.html

400. Shyam Balganesh, Foreseeability and Copyright Incentives (April 2008)

401. Cass R. Sunstein and Reid Hastie, Four Failures of Deliberating Groups (April 2008)

402. M. Todd Henderson, Justin Wolfers and Eric Zitzewitz, Predicting Crime (April 2008)

403. Richard A. Epstein, Bell Atlantic v. Twombly: How Motions to Dismiss Become (Disguised) Summary Judgments (April 2008)

404. William M. Landes and Richard A. Posner, Rational Judicial Behavior: A Statistical Study (April 2008)

405. Stephen J. Choi, Mitu Gulati, and Eric A. Posner, Which States Have the Best (and Worst) High Courts? (May 2008)

406. Richard H. McAdams and Janice Nadler, Coordinating in the Shadow of the Law: Two Contextualized Tests of the Focal Point Theory of Legal Compliance (May 2008, revised October 2008)

407. Cass R. Sunstein, Two Conceptions of Irreversible Environmental Harm (Mary 2008)

408. Richard A. Epstein, Public Use in a Post-Kelo World (June 2008)

409. Jonathan R. Nash, The Uneasy Case for Transjurisdictional Adjudication (June 2008)

410. Adam B. Cox and Thomas J. Miles, Documenting Discrimination? (June 2008)

411. M. Todd Henderson, Alan D. Jagolinzer, and Karl A. Muller, III, Scienter Disclosure (June 2008)

412. Jonathan R. Nash, Taxes and the Success of Non-Tax Market-Based Environmental Regulatory Regimes (July 2008)

413. Thomas J. Miles and Cass R. Sunstein, Depoliticizing Administrative Law (June 2008)

414. Randal C. Picker, Competition and Privacy in Web 2.0 and the Cloud (June 2008)

415. Omri Ben-Shahar, The Myth of the “Opportunity to Read” in Contract Law (July 2008)

416. Omri Ben-Shahar, A Bargaining Power Theory of Gap-Filling (July 2008)

417. Omri Ben-Shahar, How to Repair Unconscionable Contracts (July 2008)

418. Richard A. Epstein and David A. Hyman, Controlling the Costs of Medical Care: A Dose of Deregulation (July 2008)

419. Eric A. Posner, Erga Omnes Norms, Institutionalization, and Constitutionalism in International Law (August 2008)

420. Thomas J. Miles and Eric A. Posner, Which States Enter into Treaties, and Why? (August 2008)

421. Cass R. Sunstein, Trimming (August 2008)

422. Cass R. Sunstein, Second Amendment Minimalism: Heller as Griswold (August 2008)

423. Richard A. Epstein, The Disintegration of Intellectual Property (August 2008)

424. John Bronsteen, Christopher Buccafusco, and Jonathan Masur, Happiness and Punishment (August 2008)

425. Adam B. Cox and Thomas J. Miles, Judicial Ideology and the Transformation of Voting Rights Jurisprudence (August 2008)

426. Daniel Abebe and Jonathan S. Masur, A Nation Divided: Eastern China, Western China, and the Problems of Global Warming (August 2008)

427. William Birdthistle and M. Todd Henderson, One Hat Too Many? Investment Desegregation in Private Equity (August 2008)

428. Irina D. Manta, Privatizing Trademarks (abstract only) (September 2008)

429. Paul J. Heald, Testing the Over- and Under-Exploitation Hypothesis: Bestselling Musical Compositions (1913-32) and Their Use in Cinema (1968-2007) (September 2008)

430. M. Todd Henderson and Richard A. Epstein, Introduction to “The Going Private Phenomenon: Causes and Implications” (September 2008)

431. Paul Heald, Optimal Remedies for Patent Infringement: A Transactional Model (September 2008)

432. $\quad$ Cass R. Sunstein, Beyond Judicial Minimalism (September 2008)

433. Bernard E. Harcourt, Neoliberal Penality: The Birth of Natural Order, the Illusion of Free Markets (September 2008) 
434. Bernard E. Harcourt, Abolition in the U.S.A. by 2050: On Political Capital and Ordinary Acts of Resistance (September 2008)

435. Robert Cooter and Ariel Porat, Liability for Lapses: First or Second Order Negligence? (October 2008)

436. Ariel Porat, A Comparative Fault in Defense Contract Law (October 2008)

437. Richard H. McAdams, Beyond the Prisoners' Dilemma: Coordination, Game Theory and the Law (October 2008)

438. Dhammika Dharamapala, Nuno Garoupa, and Richard H. McAdams, Belief in a Just World, Blaming the Victim, and Hate Crime Satatutes (October 2008)

439. M. Todd Henderson, The Impotence of Delaware's Taxes: A Short Response to Professor Barzuza's Delaware's Compensation (October 2008)

440. Richard McAdams and Thomas Ulen, Behavioral Criminal Law and Economics (November 2008)

441. Cass R. Sunstein, Judging National Security post-9/11: An Empirical Investigation (November 2008)

442. Eric A. Posner and Adrian Vermuele, Crisis Governance in the Administrative State: 9/11 and the Financial Meltdown of 2008 (November 2008)

443. Lee Anne Fennell, Adjusting Alienability (November 2008)

444. Nuno Garoupa and Tom Ginsburg, Guarding the Guardinas: Judicial Councils and Judicial Independence (November 2008)

445. Richard A. Epstein, The Many Faces of Fault in Contract Law: Or How to Do Economics Right, without Really Trying (December 2008)

446. Cass R. Sunstein and Richard Zeckhauser, Overreaction to Fearsome Risks (December 2008)

447. Gilbert Metcalf and David Weisbach, The Design of a Carbon Tax (January 2009)

448. David A. Weisbach, Responsibility for Climate Change, by the Numbers (January 2009)

449. M. Todd Henderson, Two Visions of Corporate Law (January 2009)

450. Oren Bar-Gill and Omri Ben-Shahar, An Information Theory of Willful Breach (January 2009)

451. Tom Ginsburg, Public Choice and Constitutional Design (January 2009)

452. Richard Epstein, The Case against the Employee Free Choice Act (January 2009)

453. Adam B. Cox, Immigration Law's Organizing Principles (February 2009)

454. Philip J. Cook, Jens Ludwig, and Adam M. Samaha, Gun Control after Heller: Threats and Sideshows from a Social Welfare Perspective (February 2009) 